Federal Reserve Bank of Dallas

Globalization and Monetary Policy Institute

Working Paper No. 116

http://www.dallasfed.org/assets/documents/institute/wpapers/2012/0116.pdf

\title{
The Few Leading the Many: Foreign Affiliates and Business Cycle Comovement ${ }^{*}$
}

\author{
Jörn Kleinert \\ University of Graz \\ Julien Martin \\ IRES- Université Catholique de Louvain, Belgium \\ Farid Toubal \\ Paris School of Economics \\ University of Angers \\ CEPII, France
}

May 2012

\begin{abstract}
This paper uses micro-data on balance sheets, trade, and the nationality of ownership of firms in France to investigate the effect of foreign multinationals on business cycle comovement. We first show that foreign affiliates, which represent a tiny fraction of all firms, are responsible for a high share of employment, value added, and trade both at the national and at the regional levels. We also show that the distribution of foreign affiliates across regions differs with the nationality of the parent. We then show that foreign affiliates increase the comovement of activities between their region of location and their country of ownership. Moreover, we find greater comovement among French regions that have a more similar composition in terms of the nationality of foreign affiliates. These findings suggest that a non-negligible part of business cycle comovement is driven by a few multinational companies, and that the international transmission of shocks is partly due to linkages between affiliates and their foreign parents.
\end{abstract}

JEL codes: F23, F12, F4; F41

\footnotetext{
* Jörn Kleinert, Department of Economics, University of Graz, Universitätsstraße 15/F4, 8010 Graz. +43-316-380-3443. Joern.kleinert@uni-graz.at. Julien Martin, Université Catholique de Louvain, Pl. Montesquieu, 3, 1348 Louvain-la-Neuve, Belgium. +32-10-47-39-74. J.martin@uclouvain.be. Farid Toubal, University of Angers, Paris School of Economics and CEPII, Centre d'Economie de la Sorbonne, 106-112 bd l'hôpital , 75647 Paris cedex 13. toubal@univ-paris1.fr. We wish to thank Paul Bergin, Matthew Cole, Lionel Fontagné, Florian Mayneris, Nicolas Schmitt and Linda Tesar. This research has received funding from the European Community Seventh Framework Programme (FP7/2007-2013) under grant agreement no XXXX. Julien Martin acknowledges financial support from the FSR Marie Curie fellowship, and the ARC convention on "Geographical mobility of actors". Farid Toubal would like to thank the CEPR project "Globalization Investment and Services Trade" funded by the European Commission under FP7-PEOPLE-ITN-2008-21. The views in this paper are those of the authors and do not necessarily reflect the views of the Federal Reserve Bank of Dallas or the Federal Reserve System.
} 


\section{Introduction}

A few large firms have disproportionate influence on aggregate economic outcomes. Nokia in Finland, Dell in Ireland, Samsumg and Hyundai in South Korea are often cited as examples of the influence of a few firms on the economic activities of nations. Even in a country as large as the U.S., the sales of the top 50 firms represent about one fourth of the GDP. ${ }^{1}$ Beyond these facts, Gabaix (2011) has theorized and shown that U.S. aggregate fluctuations are greatly influenced by shocks to large firms. di Giovanni and Levchenko (2011) and di Giovanni, Levchenko and Méjean (2011) also provide systematic evidence of the key role of large firms in aggregate fluctuations. Parallel contributions point to striking heterogeneity between large and small firms. They adjust labor differently along the cycle (Moscarini and Postel-Vinay, 2009), they have different pricing strategies (Goldberg and Hellerstein, 2009), and different innovation responses (Mansfield, 1962). We document that large firms differ also in terms of their ownership structure from smaller firms. More specifically, the share of foreign affiliates is substantially larger among large firms than among smaller ones. We then provide evidence that these few but large foreign affiliates give rise to aggregate cofluctuations.

Majority-owned affiliates of foreign firms in France represent about $5 \%$ of the total number of French firms, but their contributions to the economic activities of France and its regions are substantial: they account for $23 \%$ of employment, $32 \%$ of value added, and half of total trade. Moreover, it is likely that their activities are closely linked to the environment in their source country and to the activities of their foreign parent company (Desai and Foley, 2004). They might therefore affect the correlation of business cycles between their home country and host locations.

In order to analyze the effects of foreign affiliates on business cycle comovements, we need a dataset that identifies the firms and their source country carefully, as well as their share in economic activities. We rely on detailed firm-level data from the French statistical office that include the balance sheet and the nationality of all firms located in France. The data have also detailed information on their location in each of the 21 Metropolitan French regions. We combine this information to precise data on bilateral trade and intra-firm trade. We then aggregate the data at the level of the regions and construct the share of employment generated by foreign affiliates in each region and their intensity in intra-firm trade based on their nationality.

Our econometric analysis makes use of two complementary approaches. First, we match the data to a large cross-section of bilateral pairs of correlations between the growth rate in a region's and a country's GDP. We relate business cycle comovement between French regions and foreign countries to the importance of the activities of foreign affiliates from the particular country in the region. Second, we focus on cross-region GDP correlations. We analyze whether the dissimilarity in the composition of the nationalities of foreign affiliates across regions affects cross-regional GDP correlations. This second methodology gives us the

\footnotetext{
${ }^{1}$ For figures see Gabaix (2011) and di Giovanni and Levchenko (2011). The trade literature has also stressed that the lion's share of international trade is done by a few large firms (Bernard and Jensen, 1997; Mayer and Ottaviano, 2008).
} 
advantage of carefully controlling for the similarity of production structures between regions, as it has proven to be an important determinant of business cycle correlations (Imbs, 2004). It has also the advantage of ruling out some sources of external influence, such as the exchange rate or monetary policies.

Our paper offers new insights that go beyond the findings of the literature. We contribute to the aforementioned literature on large firms by documenting an important dimension that has been overlooked; namely, their nationality and ownership. More specifically, we show that the affiliates of foreign firms are large in French regions. In Alsace for instance, they account for $10 \%$ of the regional number of firms, half of total sales and value added and about $3 / 4$ of trade. Moreover, since our data track their nationality of ownership, we document that the distribution of the activities of foreign affiliates based on their source country is uneven across regions. ${ }^{2}$ We use this heterogeneity to identify the source of business cycle correlations.

We contribute to the literature on business cycle fluctuation in four respects. First, while other studies have focused on the role of foreign direct investment (Jansen and Stokman, 2006; Hsu et al., 2011), we measure the real activity of foreign affiliates and show that they have affected the comovement of economic activities significantly. ${ }^{3}$ More specifically, the share of foreign affiliates in regional employment and the regional intensity in intra-firm trade increase the correlation between the regional growth in GDP and that of the country of ownership significantly. This result is consistent with the findings of Burstein, Kurz and Tesar (2008) who show that production sharing is an important determinant of synchronization. ${ }^{4}$ In addition, we show that this positive and significant impact of the activities of foreign affiliates is robust to the inclusion of several other potential important sources of business cycle comovement, such as bilateral trade (Frankel and Rose, 1998), sector specialization and intra-industry trade (Imbs, 2004), distance or border (Clark and van Wincoop, 2001) and demand and supply shocks. ${ }^{5}$

Second, we demonstrate that it is important to analyze business cycle comovements at the regional level. We show that the comovements within France are heterogenous. Some business cycle correlations of distant and structurally different regions are negative, while the correlations of cycles of French border regions with their neighboring countries is positive. At the same time, firms from neighboring countries are usually important actors in French

\footnotetext{
${ }^{2}$ The share of value added by US foreign affiliates in Haute Normandie is 5 times bigger than in Bretagne. The share of value added by Japanese foreign affiliates in Nord Pas-de-Calais is 3,000 times bigger than in Midi-Pyrénées.

${ }^{3} \mathrm{On}$ evidence of the effect of bilateral FDI on the comovement of OECD countries, see Jansen and Stokman (2006).

${ }^{4}$ Bergin, Feenstra and Hanson (2009) also point to the transmission of economic shocks through foreign multinationals.

${ }^{5}$ Beside the influent contribution of Frankel and Rose (1998), many papers find evidence that more bilateral trade between countries leads to more business cycle synchronization. See among others: Baxter and Kouparitsas (2005), Kose and Yi (2006), Calderon, Chong and Stein (2007), Inklaar, Jong-A-Pin and de Haan (2008). In a refinement of the literature, few papers advocate the specificity of trade in intermediate inputs or production sharing between countries Burstein, Kurz and Tesar (2008), di Giovanni and Levchenko (2010) Johnson (2011) and $\mathrm{Ng}(2010)$.
} 
border regions. Positive and close correlations of GDP growth rates are however not only a feature of adjacent regions, but can be observed for several region-country pairs. The business cycle of a foreign country might be therefore correlated or not to the business cycles of each particular region.

Third, we find that the impact of foreign affiliates on business cycle comovements has the same order of magnitude as the effect of bilateral trade. Importantly, the effect of the presence of foreign affiliates on business cycle comovements is robust to the inclusion of exogenous components of business cycle comovements such as distance and border, whereas bilateral trade is not. Within France, we show lower business cycle comovements between more dissimilar regions. This effect is robust to the inclusion of production similarity, distance and border and regional fixed effects. In other words, we find the multinational linkage to be more robust than the trade linkage.

Fourth, we provide evidence that, on top of country and sector determinants of cofluctuations emphasized in the literature, the characteristics of firms such as size and foreign ownership matter to understand business cycle comovement.

The remainder of this paper is structured as follows. Section 2 provides a discussion of the source of the influence of foreign affiliates on business cycle correlations. Section 3 provides a thorough discussion of the data and the construction of the bilateral database. In section 4, we provide three sets of stylized facts that show (i) the importance of foreign affiliates in regional economic activities, (ii) the spatial distribution of investors in French regions based on their nationality and (iii) the unconditional correlations between the GDP growth of regions and countries. Section 5 describes the empirical methodology and discusses the construction and sources of the main empirical variables. In section 6 , we present the econometric results. Section 7 concludes.

\section{Sources of Influence}

Most works looking at the determinants of business cycles were originally motivated by the possibility of an endogenous optimal currency area. Frankel and Rose (1998) argue that more integration leads to a greater business cycle synchronization. From a theoretical point of view, more trade does not necessarily lead to comovement. It depends on the nature of shocks and the patterns of trade. For instance, productivity shocks should lead to a greater specialization of countries in a world of inter-industry trade, and thus less comovement. By contrast, in a world of intra-industry trade, the same shocks should have the opposite effects. A deeper discussion can be found in di Giovanni and Levchenko (2010). Similarly to trade, the link between the presence of foreign affiliates and business cycle comovement depends on the pattern of linkages between the parent and its affiliates and the nature of the shocks. However, since we now look at firms, a third element of influence matters, namely the size of the foreign affiliates. In order to understand the role of foreign affiliates in the synchronization of business cycles, we need first to establish the conditions under which the shocks are transmitted from the parent to the affiliates. We will then explain the transmission to the economic aggregates and explain the comovement of business cycles. 
Assume the two extreme cases of vertical and horizontal multinational firms. Vertical multinationals fragment their production process across geographic space. The parent and its affiliates are related through trade in intermediate inputs. In such cases, any demand shocks will transmit to each stage of the chain, inducing strong linkages between the activities of the parents and the affiliates. A productivity shock or a technology shock may have similar consequences. If the multinational firm is horizontal and the foreign affiliates produce for the local market, then a local demand shock to the parent or to the affiliates should have no effect on one or the other. The reason is that in this extreme case, the production of the affiliates and the parent are independent. A positive correlation of activities would simply reflect that demand shocks for the parents and the affiliates are correlated. In the case of productivity or technology shocks, the impact on the correlation of activities in unclear. One possibility is that the parents which receive a technology shock transfer the technology to their affiliates. This would lead to a positive correlation of economic activities. Recent evidence provided by Ramondo, Rappoport and Ruhl (2011) shows vertical relationships between parents and affiliates without intra-firm flows. They suggest multinational firms transfer intangible inputs through the production chain. Such transfer could also be the source of linkages between parents and affiliates. In the same vein, Atalay, Hortacsu and Syverson (2012) provide evidence that, in the US economy, vertical linkages between firms are not primarily concerned with goods' trade. They show however that such structure allows firms to transfer intangible inputs.

Production sharing or technology transfers explain the positive correlation of activities and the transmission of shocks between parents and affiliates. Assume now that this transmission takes place. We need to understand how the relation between the parent and the affiliates might influence aggregate business cycle comovement. We suppose first that the parent faces a macroeconomic shock. Examples of such macro-shocks include a new technology available in the country or a natural disaster. In such cases, if the foreign affiliates are sufficiently large, then their own activities have a non-negligible impact on the activities of their regions of location. The macroeconomic shock in the parent country is thus transmitted to foreign affiliates and to the foreign country, which induces a correlation of activities between the two economies. ${ }^{6}$

If the parent faces idiosyncratic shocks, then it must be large enough to drive output fluctuations in its domestic country. Gabaix (2011) shows that part of the US GDP slowdown in 1970 was driven by a 10-week-long strike at General Motors. If this type of shock is transmitted to foreign affiliates, they might influence the fluctuation of GDP in their host country, given that they are also large enough.

In this paper, we do not investigate the type of shock and the nature of the relationship between the parent and its affiliates. Our aim here is to examine the role of foreign affiliates in business cycle synchronization. We need the activities of affiliates to be correlated to the activities of their parent. These foreign affiliates must also be important in the economic

\footnotetext{
${ }^{6}$ For instance, the recent tsunami in Japan has strongly affected Japan's GDP and all Japanese firms and might also have affected the regions of location of their activities if their foreign affiliates were sufficiently large.
} 
activities of the regions where they are located. In the remaining of the paper, we document that foreign affiliates are large enough in French regions to transmit shocks. We also provide reduced form evidence that the presence of foreign affiliates affects the correlation of the business cycles between their host regions and their country of ownership positively.

\section{The Data}

We build a database that describes value added, employment, and sales in French regions, as well as these regions' bilateral exports to and imports from 162 partner countries (with a distinction between trade between related parties and arm-length trade) in the manufacturing, extractive, and agricultural industries. Within regions, this information is disaggregated based on the ownership status of the firm. Namely, we distinguish the economic activities of independent firms, French affiliates, and foreign affiliates.

The dataset is based on the the aggregation of five confidential micro-datasets that are provided by different French administrations. The data are then matched to a vector of bilateral correlations of business cycles between 21 Metropolitan French regions and 162 countries. We briefly describe the main traits of our database in the next paragraphs. We give more details on the data and data processing in the data appendix (Appendix A)

The balance-sheet information on sales, value added, and employment is taken from the $B R N$ data (Bénéfice Réel Normal). The BRN is a compulsory report for all firms that have an annual turnover of more than 763,000 euros. In order to identify the ownership status of the firms, we use the LIFI data which is an administrative dataset on the ownership and nationality of the parent company of firms located in France (LIaison FInancière). ${ }^{7}$ We classify firms based on their nationality and ownership. According to the French statistical institute (INSEE), a firm is an affiliate of a group if the latter has the (direct or indirect) majority of voting rights. In our data, the share of voting rights owned by the parent firms varies from $50 \%$ to $100 \%$. While the average share of voting rights is $86 \%$, the median is $99 \%$. We can therefore expect the parent company to exert a control on the decisions of the majority-owned affiliates. We distinguish between foreign and French affiliates. A French affiliate, which we denote by $M N E$, is loacted in France and owned by a French group. We denote the foreign affiliates by FME, which are located in France and owned by a foreign group. We also keep track of their nationality whenever they are foreign-owned. The residual group of firms is denoted by $I N D$. It is composed of firms that are located in France, but that are not owned at a majority by a group.

Data on bilateral exports and imports of firms located in France are provided by French Customs. In 2004, $15 \%$ of the total number of registered firms are engaged in foreign trade (exports, imports or both). Yet the participation of firms to foreign trade differs to a great extent with their ownership structure and nationality. Among the three categories of firms defined above, the group of independent firms is far less internationalized than the group of

\footnotetext{
${ }^{7}$ All firms with more than 500 employees or a turnover above one million euros are asked about their ownership and financial structure. This includes their links with small businesses, which allows us to have information on small foreign affiliates.
} 
affiliates of French firms. While we only find $9.6 \%$ of the total number of independent firms that are trading, there are respectively $36 \%$ of French affiliates and $78 \%$ of foreign affiliates that participate to foreign trade.

We also use information on intra-firm trade as an alternative measure of the presence of foreign affiliates. ${ }^{8}$. We use the EIIG firm-level survey (Échanges Internationaux IntraGroupe) from the INSEE which provides a detailed geographical breakdown of the import and export value of French firms and their sourcing modes - outsourcing and/or intra-firm trade.

At this stage, our data consist of a comprehensive panel of 184,929 firms, for the 1999-2004 period. A firm located in France might have branches in different regions. When it comes to filing the BRN or the Customs' forms, the value added, sales or trade values are always allocated to the region of location of the headquarters. We follow the INSEE methodology and reallocate the value added, sales and trade of multi-plant firms across regions. ${ }^{9}$ The statistics are then aggregated to the level of each of the 21 Metropolitan regions.

This database at the regional level is combined with a dataset that contains the correlation of the business cycles between a French region $i$ and a partner country $c$. We consider 162 partner countries over the 1990-2006 period. ${ }^{10}$ As a measure of regional GDP, we use the publicly available yearly GDP computed by INSEE over the 1990-2006 period. We combined it with World Bank yearly data for the GDP of the countries, in current US dollars. The database is completed with the total exports and imports of the partner countries, that we take from the Direction Of Trade Statistics (DOTS). ${ }^{11}$

\section{Firms in French Regions: Nationality and Owner- ship}

As discussed in Section 3, there are two necessary conditions for business cycles to be transmitted across borders by multinational firms. First, the activities of the parent and foreign affiliates must be positively correlated. Second, foreign affiliates must be large enough to affect aggregate fluctuations in their host regions. The first condition was recently documented by Desai and Foley (2004) who show a positive correlation between the activity of parents and foreign affiliates. There is also a large literature on intra-firm trade which shows that parent companies organized their production at a global scale using their networks of foreign affiliates (Helpman, 2011). At first sight, the second condition is less obvious. The first set of statistics provides evidence on the importance of domestic and foreign affiliates for the output of their region of location.

\footnotetext{
${ }^{8}$ Note that (Burstein et al., 2008) use it as a proxy for production sharing.

${ }^{9}$ In our sample, only $1.8 \%$ of firms are multi-plant and multi-region. Yet these firms account for $9.8 \%$ of total employment.

${ }^{10}$ The correlation of the cycles between region $r$ and country $c$ is computed either as the correlation in the annual growth rates or as the correlation of HP-filtered GDPs.

${ }^{11}$ As detailed in Appendix A, values in dollars are converted into euros using the euro-dollar exchange rate from Eurostat.
} 
In the empirical analysis, we use French regional data to measure the correlation between the presence of multinationals and business cycle comovement. Thus, we need some heterogeneity across regions to identify our econometric model. The second set of descriptive statistics intends to show that there are disparities across regions in i) the intensity of the production of foreign multinational affiliates, ii) the origin of those foreign affiliates, and iii) in the pattern of aggregate cofluctuations.

\subsection{The Key Role of Foreign Affiliates}

It is well documented that multinational firms represent only a tiny fraction of the total number of firms. However, the aforementioned literature has emphasized that even a few firms may contribute substantially to GDP and employment. We aim to show that the affiliates of foreign firms explain a non-negligible part of aggregate co-fluctuations despite their low number and because they are the largest firms. ${ }^{12}$

In Table 1, we provide a regional breakdown of the yearly contribution of independent firms, French affiliates, and foreign affiliates for six different outcomes: number of firms, employment, sales, value added and exports and imports. Perhaps the most informative feature of Table 1 is the disproportionate role of affiliated firms - foreign affiliates in particular - in aggregate outcomes.

- Table 1 about here -

There are at least three interesting facts that emerge from this table.

1. Foreign affiliates and French affiliates account for the vast majority of employment, sales and trade while they represent very few firms (5.2\% of firms are FMEs and $17.2 \%$ are MNEs). French affiliates account for more than $41 \%$ of employment, sales and value added. Foreign affiliates account for about $1 / 3$ of value added and sales and more than $22 \%$ of employment.

2. We find that trade is extremely concentrated among the group of foreign affiliates. On average, FMEs which represent $5.2 \%$ of the total number of firms account for about $47 \%$ of exports and more than $56 \%$ of imports. The contribution of French affiliates to international trade is also sizeable. They account for one third of French imports and $40 \%$ of French exports.

3. The concentration is very pronounced in some regions as Alsace or Bretagne. In Alsace, $10 \%$ of firms are foreign-owned while they represent about $50 \%$ of value added, $70 \%$ of exports and $80 \%$ of imports. In Bretagne, foreign affiliates represent about 3 percent of firms in the region, but make up $15 \%$ of the region's value added and about $2 / 3$ of its trade (import and export).

Among the group of foreign affiliates, the concentration of economic activities rests on very few firms as shown in Table 2. In Auvergne, the five largest foreign affiliates account

\footnotetext{
${ }^{12}$ Note that we do not focus the analysis on idiosyncratic shocks driving comovement.
} 
for two-thirds of the total value added of all foreign affiliates. Taking the 10 largest foreign affiliates, this share reaches $73.8 \%$. Given that foreign affiliates account for more than $30 \%$ of Auvergne's value added, the ten largest foreign affiliates account for more than $22 \%$ of the regional value added. Auvergne is not a particular case, the concentration of economic activities in the hands of a few foreign affiliates can be observed across regions. ${ }^{13}$ With respect to trade, the importance of the largest foreign affiliates is even more pronounced.

- Table 2 about here -

Stylized facts from Tables 1 and 2 point to the importance of foreign affiliates in the regions. A change in their output or trade activities will affect regional GDPs directly. Adding indirect effects, through the link to local suppliers and customers, the impact of foreign affiliates would probably be even larger.

In Figures 1, and 2, we refine our arguments by comparing French and foreign firms in France. We investigate the ownership breakdown of the share of value added by the largest $1 \%$ firms. We also show figures on the composition of firms in the remaining sample, once we exclude the top $1 \%$ firms.

- Figures 1, and 2 about here -

The results are striking. About 30 to 70 percent of the largest (top1\%) firms have a foreign ownership. Less than 10 percent are independent. By contrast, as we show in Fig. 2 , the remaining group of firms is mostly made up of independent firms and the share of foreign affiliates is never greater than 10 percent. ${ }^{14}$. This fact suggests that firms are not only different with respect to their size and that few firms are sizably larger than other firms, but they are also different in terms of their ownership structure.

Figure 3 displays a box-plot that depicts the highest and smallest ranks, as well as the first, second, and third quartiles of ranks of foreign affiliates among the 500 largest firms in every French region. It shows that FMEs tend to be the largest among the largest firms. More specifically, one can see that the distribution of ranks has median and first and third quantiles on the left of the figure, meaning foreign affiliates tend to have ranks closer to 1 than to 500, in almost every region. On can also see that the minimum rank is close to zero, meaning that among the 10 largest firms in the regions, some are foreign affiliates. Eventually, a glance at the data reveals that on average half of the 10 largest firms in French regions are foreign affiliates.

- Figure 3 -

\footnotetext{
${ }^{13}$ For instance, the ten largest foreign affiliates account for $19.1 \%$ of total value added in Alsace, $18.3 \%$ in Lorraine, and $12.8 \%$ in Picardie.

${ }^{14}$ The information on the ownership of firms comes from LIFI. As discussed in Appendix A, this survey is exhaustive for firms with an annual turnover above 1 million euros and firms with more than 500 employees. If we focus on the sample of firms that are above one of these thresholds, we drop half of the firms, but the remaining ones account for $94 \%$ of total value added. Focusing on this reduced sample of firms, we find the same difference in the composition of the top $1 \%$ against the others. In particular, FMEs are over-represented in the largest $1 \%$ firms of this sample. Namely, FMEs account for $49 \%$ of the top $1 \%$ and MNEs account for $42 \%$. By contrast, FMEs account for only $9.5 \%$ of the smallest firms, and MNEs $33 \%$
} 


\subsection{The Importance of the Nationality of Ownership}

We have shown that foreign affiliates constitute a large share of regional employment, value added and trade. Another important dimension concerns their country of ownership. In order to have an impact on business cycle comovement, affiliates from a particular foreign country must contribute to a significant share of regional outcomes. In France, $55 \%$ of the number of foreign affiliates are owned by parents from the United States, Spain, Germany, the United Kingdom, and the Netherlands. They account for more than two-thirds of the total value added made by foreign affiliates. ${ }^{15}$

To be able to use the cross-region dimension of the data, we need some heterogeneity with respect to the nationality of foreign affiliates across regions. The share of value added is expected to be high for some investors in bordering regions, but the border alone cannot explain the location of activities and the comovement. Fortunately, the shares of value-added by country of ownership are not evenly distributed across all regions. It is interesting to look at the regional distribution of the shares of value added by important source countries; two sharing a border with France (Germany and Spain) and two outside Europe (the U.S. and Japan). This is represented in Figure 4.

- Figure 4 about here -

These maps show that the value added shares of German affiliates is large in AlsaceLorraine, but also very large in Midi Pyrénées, which does not share a border with Germany. ${ }^{16}$ Spanish affiliates contribute largely to the value added created in Pays de la Loire and not in the neighboring regions of Midi-Pyrénées or Aquitaine.

An interesting link between foreign affiliates and their country of ownership is intrafirm trade. It has been proved to be a particulary important determinant of business cycle comovement (Burstein et al., 2008). Table 3 reports evidence on intra-firm exports and imports by French and foreign affiliates across French regions. The first set of results from Table 3 stems from the comparison of exports (columns 1 and 3) and imports (columns 2 and 4) by French and foreign affiliates. While the share of intra-firm trade is already high for French affiliates, it appears that this share is even larger for foreign affiliates. This is particularly relevant for imports. The share of intra-firm imports by foreign affiliates is at least twice the share of intra-firm imports by French affiliates. ${ }^{17}$ The table shows that there is an important degree of heterogeneity across regions. About $31 \%$ of the trade of affiliates in Aquitaine is intra-firm, while it is $75 \%$ for Centre.

- Table 3 about here -

There are multiple linkages between foreign affiliates and their country of ownership. Our data reveal that $13.6 \%$ of total exports and $25.6 \%$ of total imports of foreign affiliates are with their country of ownership. This is substantial given the large cross-section of countries that we have in our sample. Furthermore, the last two columns of Table 3 show that almost three

\footnotetext{
${ }^{15}$ In Figure 5 of Web appendix E, we show the geographic origin of foreign investors in France.

${ }^{16}$ With the presence of large affiliates such as Airbus Deutschland and Siemens VDO Automotive.

${ }^{17}$ Given the share of intra-firm trade for MNEs and FMEs, and the share of FMEs and MNEs in total trade, about $40 \%$ of French exports and $45 \%$ of French imports are intra-firm. As a comparison, Bernard, Jensen, Redding and Schott (2010) report that $46 \%$ of US imports are intra-firm.
} 
quarters of the total trade between foreign affiliates and their parent country is intra-firm.

\subsection{Heterogeneity in Comovement Across Regions and Countries}

We now turn to the bilateral correlation between French regional GDPs and the countries studied. If there were only one French business cycle, the regional dimension would not add to the explanation of comovement. In Table 4, we report the correlation of GDP growth between French regions. While the correlation is as high as 0.9 for a few regions, the correlation is very low and even negative for other pairs. Hence, French regions do not share perfectly correlated business cycles. We shall use this characteristic later on when we analyze the impact of foreign affiliates on business cycle correlations between French regions.

- Tables 4 and 5 about here -

In Table 5, we report the maximum and minimum correlations of French regions with Germany, Spain, the U.S. and Japan. For Germany and Spain, the unconditional correlation of GDPs is among the highest with the regions where their foreign affiliates represent a substantive share of regional value added. Unexpectedly, we find a negative unconditional correlation for the U.S. and Japan in the regions where they account for a large share of value added.

These stylized facts show that there is heterogeneity in the GDP growth correlations along two dimensions. First, a single country might have a high level of synchronization with some regions and not others. This is the case of Germany both with Alsace and Auvergne. Second, a single region might have a high level of correlation with one country but not with another. This is the case of the GDP growth of Alsace which is positively correlated to German GDP growth but not to Spanish GDP growth.

\section{$5 \quad$ Empirical Methodology}

We propose two complementary strategies to analyze the influence of foreign affiliates on business cycle correlations. In the first approach, we focus on the impact of foreign affiliates on the correlations of GDP growth rates between 21 Metropolitan regions and 162 countries. This large cross-section of correlations therefore has information on countries that do not invest in France. They might however share a trade relationship so that we do not discard them. ${ }^{18}$ The sample has enough variation to include region- and country-specific effects, which control for demand and supply shocks. A drawback of this first approach is that the data do not allow to approximating for the similarity in the production structure. Intraindustry trade, which we include as a covariate in the analysis, is a crude proxy for it.

\footnotetext{
${ }^{18}$ The results hold if we only account for the positive value of the foreign affiliates shares because there are enough heterogeneity in the regional distribution of activities across countries of origin. We follow two methodologies. We either introduce in the regressions a dummy which account for the presence of the country of origin in the region or we discard the zero values of the shares in the bilateral pairs. The results are qualitatively similar and in line with our main findings. They are available upon request.
} 
In the second approach, we are therefore focusing on the correlation of GDP growth rates between French regions. We investigate whether regions that show a similar composition in terms of the nationality of foreign affiliates are more synchronized than regions that have a dissimilar composition. This second methodology enables to control rigorously for the similarity in the production structure between two given regions. As noticed by (Imbs, 2004), this similarity is an important determinant of business cycle comovement. An important advantage of using this second approach is that French regions are similar along many dimensions. They share identical regulations and institutions. The language is the same across regions and there are no tariff barriers between regions. Most fiscal and labor policies (such as the minimum wage) are decided at the country level, while the monetary policies are decided at the European level. When focusing on French regions, we are confident that these characteristics do not drive the differences in the co-fluctuation between French regions. A drawback of this approach is that we do not observe bilateral trade between regions. However, as shown in the empirical trade literature, bilateral trade is predicted by GDPs, distance and borders. We add country and region fixed effects to the analysis and we include distance and borders in our regressions.

A potential concern of both approaches is endogeneity. Neither measurement errors, nor omitted variable bias are an important concern since we have high quality and almost exhaustive data. We are also able to control for almost all possible determinants emphasized in the literature. Reverse causality may be an issue. However, if most parent-affiliate linkages are horizontal, firms should find it optimal to locate affiliates in a region decorrelated with their region of origin (Ramondo and Rappoport, 2010). So, this biases our results downward, meaning that our estimates are a lower bound. If the links are vertical, then reverse causality is more doubtful. Actually, to our knowledge, there is no theory in which the correlation between the region of location of the parent and the affiliate is a motive for the location of foreign affiliates. It may be that the two are correlated, because the industry structure of the region of location implies that the region of the parent and the affiliates are correlated. However, once we control for the characteristics of the regions and the similarity of the production structure, the effect of business cycle comovement on the decision of location should be negligible.

\subsection{Foreign Affiliates and Comovement Between Regions and Coun- tries}

Our analysis focuses on the correlation of GDP growth rates between 21 Metropolitan French regions and 162 countries over the 1990-2006 period. The correlation between region $r$ and country $c, \rho_{r c}$, is used as the main dependent variable. The correlation is defined as follows:

$$
\rho_{c r}=\operatorname{corr}\left(\frac{G D P_{c, t}-G D P_{c, t-1}}{G D P_{c, t-1}}, \frac{G D P_{r, t}-G D P_{r, t-1}}{G D P_{r, t-1}}\right)
$$

In a robustness check, we also use the correlation of the cyclical components of regional 
GDP and country GDP. We use the Hodrick-Prescott (1997) filter for de-trending the GDP. ${ }^{19}$ To examine the effect of foreign affiliates on business cycle comovement empirically, we estimate the following cross-section equation where the covariates are taken for 2004 .

$$
\rho_{c r}=\alpha F M E_{c r}+X_{c r} \beta+\nu_{r}+\nu_{c}+\epsilon_{c r}
$$

$F M E_{c r}$ is an indicator of the importance of foreign affiliates from country $c$ in region $r$. $X_{c r}$ is a matrix of other covariates. We control for the demand and supply shocks by adding two vectors, $\nu_{r}$ and $\nu_{c}$, of country and region fixed effects. $\epsilon_{r c}$ is the disturbance term.

As argued by Lipsey (2008), the measurement of the location of the production of a multinational might be influenced by the tax strategies followed by the parent firm. The measurement of the $F M E_{c r}$ indicator is not straightforward. In order to control for the importance of foreign affiliates in French regions, we take employment rather than value added because we believe that employment is less subject to manipulation for tax reasons (Lipsey, 2008). $F M E_{c r}$ is the the share of employment by foreign affiliates of country $c$ in region $r$.

$$
F M E_{c r}=\frac{\sum_{f} E m p_{f c r}}{E m p_{r}}
$$

where $E m p_{f c r}$ is the employment of firm $f$ with ownership from $c$ in region $r$. The denominator, $E m p_{r}$ is the total employment in region $r$. In Table 14 and 15 of Appendix E, we reproduce our results using the share of the value added of foreign affiliates from country $c$ in the GDP of region $r$ as an alternative measure of the importance of foreign affiliates.

The comovement of business cycles might be driven by foreign affiliates because of production sharing motives with their country of ownership. We construct an indicator of the intensity of intra-firm trade between the foreign affiliates in $r$ and their parents in $c, I F_{c r}$. This variable is constructed as follows:

$$
I F_{c r}=\frac{\sum_{f \in C}\left(I F E X_{f c r}+I F I M_{f c r}\right)}{G D P_{r}}
$$

where $I F E X_{f c r}$ is the value of intra-firm export from the affiliates in region $r$ to the parents in country $c$. IFIM $M_{f r}$ is the value of intra-firm import of the affiliates in region $r$ from the parents in country $c$. As the intra-firm trade variable is constructed from a survey, it is not directly comparable to the regional share of employment of foreign affiliates. In the following regression analysis, we will investigate their effect separately.

The literature has emphasized other important determinants of business cycle comovement. We include them in the $X_{r c}$ matrix. A first important factor relates to bilateral trade intensity (Frankel and Rose, 1998). We construct the index of bilateral trade intensity as the ratio of exports and imports between country $c$ and region $r$ over the sum of the region

\footnotetext{
${ }^{19}$ Since we use yearly data, we apply a smoothing parameter of 6.25 as recommended by Ravn and Uhlig (2002).
} 
and country GDP.

$$
B T_{c r}=\frac{x_{c r}+m_{c r}}{G D P_{c}+G D P_{r}}
$$

where $x_{c r}$ denotes the value of exports from $r$ to $c$ and $m_{c r}$ represents the value of imports to $r$ from $c$.

It has also been shown that the productive structure as well as the structure of bilateral trade are key determinants of business cycle comovement (Imbs 2004). The computation of an index of dissimilarity is thereby based on detailed sector data. Yet we do not have harmonized data to compare regions and countries. ${ }^{20}$ We cannot compute an accurate measure of dissimilarity from the production data. Yet it is important to control for the similarity of regions and countries, since more similar partners are likely to face the same supply and demand shocks. A higher similarity should therefore lead to a greater synchronization of business cycles. Instead of relying on production data, we use information on the structure of bilateral trade between countries and regions. The French Customs data is therefore taken to allocate exporters and importers across regions. We then calculate an index of Grubel and Lloyd for each pair of country and region.

$$
I I T_{c r}=1-\frac{\sum_{k}\left|X_{c r}^{k}-M_{c r}^{k}\right|}{\sum_{k} X_{c r}^{k}+M_{c r}^{k}}
$$

where $X_{c r}^{k}$ and $M_{c r}^{k}$ are the exports to and imports from country $c$, by region $r$, for sector $k$. In our analysis, we consider 4-digit level sectors of the HS nomenclature. An index close to one means that country $c$ and region $r$ trade similar types of products: they are engaged in intra-industry trade.

It is also likely that regions and countries that are geographically close to each other are affected by similar demand and supply shocks (Clark and van Wincoop, 2001). To capture geographical proximity, we use the distance and the presence of a common border between region and country. The border variable, Border $r_{r c}$ equals one if country $c$ and region $r$ share a common border. To compute the distance between country $c$ and region $r$, we first identify the latitude and longitude of each firm in our sample and of the capital city of each country. We then compute the distance between each firm and each country. The distance between region $r$ and country $c$ is the arithmetic average of the individual distance that separates the firms of region $r$ and the capital of country $c$.

$$
\text { Dist }_{r c}=\frac{\sum_{f \in\{r\}} \operatorname{dist}_{f c}}{N_{f}^{r}}
$$

where dist $_{f c}$ is the distance between firm $f$ (from region $r$ ) and the capital of country $c$, and $N_{f}^{r}$ is the number of firms in region $r$.

\footnotetext{
${ }^{20}$ The INSEE provides data on very few sectors: Agriculture (ISIC A-B), Mining and Utilities (ISIC C-E), Manufacturing (ISIC D), Construction (ISIC F), Wholesale and Retail (ISIC G-H), Transport, Storage and Communication (ISIC I), Other Activities (ISIC J-P). It is not possible to match this information with information on value added provided at sector level by UNIDO or TradeProd data.
} 
There are other factors that might influence the synchronization of business cycles. Kose and Yi (2006), Imbs (2004) and more recently Kalemli-Ozcan, Papaioannou and Peydró (2009) show that increased financial integration affect business cycle comovement across countries. We do not have information on this later determinant. However, the region fixed effects should control for the overall financial integration.

\subsection{Intra-national Business Cycle Correlations}

While the first part of the econometric analysis focuses on the correlation of French regions with foreign countries, our data allow to investigate the role of foreign affiliates in the business cycle comovement between French regions. In other words, we can investigate whether the importance of German affiliates in regions such as Alsace and Midi-Pyrénées contribute to the synchronization of the cycles in these regions. The bilateral correlation of the 21 French regions is measured using both the GDP growth rates and the HP-filtered GDP over the 1990-2006 period.

We examine whether French regions that have the same composition of foreign affiliates in terms of ownership exhibit a higher comovement in their business cycles. Therefore, we construct an indicator, DisFME, that measures the similarity in the composition of the nationality of ownership between French regions:

$$
D i s F M E_{r r^{\prime}}=\sum_{c}\left|\frac{E m p_{r c}}{E m p_{r}}-\frac{E m p_{r^{\prime} c}}{E m p_{r^{\prime}}}\right|
$$

where $r$ and $r^{\prime}$ are two French regions, $E m p_{r c}$ is the employment in region $\mathrm{r}$ made by foreign affiliates owned by firms from country $c$, and $E m p_{r}$ is the total employment of region $r$. The index takes a value of 0 for pairs of regions having the same composition of intensity in the value added shares of foreign affiliates. Notice that the share $\frac{E m p_{r c}}{E m p_{r}}$ sums to one if all the jobs of region $r$ are made by foreign affiliates.

While the dissimilarity of production structures cannot be properly computed when comparing French regions and countries, such a measure can be computed when we analyze the business correlation between regions. The similarity index is calculated as follows:

$$
S_{r r^{\prime}}=\sum_{k}\left|s_{r k}-s_{r^{\prime} k}\right|
$$

where $s_{r k}$ is the share of sector $k$ in the GDP of region $r$. The data on the contribution of the different sectors to the GDP of the regions are from the Comptes regionaux provided by the INSEE. The Comptes regionaux distinguish five sectors: agriculture and fishing, industry, building, and two broad classes of services.

Ideally we should control for the bilateral trade between French regions. However, we do not have such data. Instead, we use the standard gravity determinants to proxy bilateral trade between French regions. ${ }^{21}$ To do so, we introduce a border dummy in our regressions,

\footnotetext{
${ }^{21}$ Results on the international business cycle correlation show that once we control for the gravity variable, the effect of bilateral trade is no longer significant.
} 
the bilateral distance separating French regions and a full set of region fixed effects.

We construct the distance between French regions from the information on the distance across French departments. ${ }^{22}$ The bilateral distance between two regions is the weighted average of the distances between all the departments of the two regions:

$$
\text { Dist }_{r r^{\prime}}=\frac{1}{N_{d} N_{d^{\prime}}} \sum_{d \in r} \sum_{d^{\prime} \in r^{\prime}} d i s t_{d d^{\prime}}
$$

where $d$ and $d^{\prime}$ are the departments of regions $r$ and $r^{\prime}$ respectively, and $N_{d}$ and $N_{d^{\prime}}$ are the number of departments of regions $r$ and $r^{\prime}$.

Finally, we estimate the following equation that links the bilateral correlation of cycles between pairs of regions with the similarity of their FME ownership, the similarity of their production structure, the bilateral distance between the two regions and a dummy equal to one if the regions have a common border:

$$
\rho_{r r^{\prime}}=\alpha \ln \left(\operatorname{DisFME}_{r r^{\prime}}\right)+\beta \ln \left(S_{r r^{\prime}}\right)+\gamma \ln \left(\text { Dist }_{r r^{\prime}}\right)+\eta \text { Border }_{r r^{\prime}}+\mu_{r}+\mu_{r^{\prime}}+\xi_{r r^{\prime}}
$$

The descriptive statistics of the variables used in both approaches are given in Table 6 .

\section{Econometric Results}

In this section, we successively implement the two empirical methodologies and present the results. The first part investigates the impact of foreign affiliates on the GDP growth rate correlations between French regions and the countries studied. We show a positive correlation between the share of employment by foreign affiliates and the business cycle comovements between their region of location and their parent country. Bilateral trade is not statistically significant when we control for bilateral distance and adjacency. As emphasized in the empirical trade literature, these latter covariates are important predictors of trade. In our second methodology, we investigate the role of foreign affiliates and their different nationalities for the bilateral correlation of business cycles across French regions. We control for the role of the similarity of production structures between regions. We show that the dissimilarity in the nationality of ownership reduces the correlation in business cycles.

\subsection{Foreign Affiliates and Comovement between Regions and Coun- tries}

\subsubsection{The Impact of the Share of Employment of Foreign Affiliates}

The regression results are presented in Table 7. As a reminder; we are interested in the impact of foreign affiliates from country $c$ that are located in region $r$ on business cycle comovement. Our variables of interest are the employment share of foreign affiliates and the

\footnotetext{
${ }^{22}$ Departments are districts within regions.
} 
trade variables. ${ }^{23}$ The specifications include region and country fixed effects to control for country- and region- specific shocks. Our specifications with fixed effects explain about $69 \%$ of the variation of the business cycle correlations. ${ }^{24}$

Looking across each specification in Table 7, we see strong evidence that the share of employment by foreign affiliates increases the correlation between their country of ownership and the region of location. In addition to the share of employment produced by foreign affiliates, we also find evidence that bilateral trade and intra-industry trade have positive effects on the synchronization of business cycles. As we will see later on, their effects are however less robust. Compared to column (2), the bilateral trade variable is estimated with a lesser degree of precision once we include the $F M E_{c r}$ variable in column (3). This is an indication of the importance of foreign affiliates in the bilateral trade of the regions.

In order to show that the impact of the share of employment by foreign affiliates is not only significant but also quantitatively important, we have computed the standardized coefficient of the $F M E_{c r}$ variable. Based on the preferred estimates from (5) that include full sets of fixed effect controls, the standardized coefficient of the $F M E_{c r}$ variable is 0.06 while the standardized coefficient of the $B T_{c r}$ variable is 0.03 . The effect of foreign affiliates is therefore large enough to be of substantive interest. Since we estimate a linear model, we can evaluate the elasticity of the $F M E_{c r}$ variable at mean values. Taking information from Table 6 , we find that a $10 \%$ percent increase in the employment share of foreign affiliates raises the business cycle correlation between their country of ownership and their region of location by about $0.5 \%$. The bilateral trade variable as well as the intra-industry trade variable are however not significant once we control for the exogenous component of business cycles, such as bilateral distance and borders. Note that distance and borders do not influence the coefficient of the employment share of foreign affiliates significantly.

Our explanatory variables are computed for the year 2004. Table 8 repeats the crosssectional estimates of columns 5 of Table 7 using explanatory variables computed from 1999 to $2004 .^{25}$ As we can see, the results barely change and the robustness is high. Note that in four columns, the coefficient of the intra-industry trade variables enters the specifications significantly (at a $10 \%$ level).

In Table 9, we use the HP-filtered GDP correlations as a dependent variable. The estimated coefficients of the $F M E_{c r}$ variable is now halved, but it is still economically important. Given the information in Table 6 , we find that a $10 \%$ percent increase in the employment share of foreign affiliates raises the HP-filtered GDP correlations by about $0.17 \%$. While estimated with a lower degree of precision, the coefficient remains statistically significant. As in Table 7, we do not find any evidence of a significant effect of the trade variables.

In Tables 14 and 15, we show that our results are qualitatively similar when measuring

\footnotetext{
${ }^{23}$ In Appendix E, we reproduce Table 7 and 9 using the foreign affiliate value added share in the regions rather than their employment share. The results are qualitatively similar using both the correlations in growth rate as well as the HP-filtered GDPs.

${ }^{24}$ The specification without fixed effects explains about $3 \%$ of this variation. This finding is in line with Baxter and Kouparitsas (2005), who find a similar $R^{2}$ in the univariate analysis of trade on business cycle comovement.

${ }^{25}$ The GDP correlations are computed over the 1990-2006 period.
} 
the presence of foreign affiliates by value added rather than employment.

\subsubsection{The Impact of Intra-firm Trade}

In this section, we investigate the effect of intra-firm trade on comovement. We view intrafirm trade as an alternative measure of the presence of foreign affiliates. With this measure, whatever the specification, the findings are qualitatively the same as the results measuring the presence of foreign affiliates through employment or value added. We go a step further Burstein, Kurz and Tesar (2008) by taking the nationality of ownership of the foreign parents and the regional dimension into account. Table 10 reports regression results of business cycle correlations on the intra-firm trade of foreign affiliates. ${ }^{26}$ We further use the correlation between HP-filtered GDP growth rates as a dependent variable in Table 11. Our specifications include both country- and region-specific effects. They explain about $69 \%$ of the variation in business cycle comovement.

We find a positive and significant impact of the intra-firm trade of affiliates with their parent countries on business cycle correlations. The estimated coefficients are robust across specifications and are estimated with a large degree of precision. Computing the elasticity at the means of the independent variables in column 5, we find that a $10 \%$ increase in intrafirm trade intensity raises the GDP growth rate correlations by $0.18 \%$. The estimates of the intra-firm trade variable remains significant even if we include the bilateral distance and border variables.

As in Table 7 and 9, the effect of the bilateral trade variables is not robust across specifications. The impact of bilateral trade is not statistically significant once we introduce the bilateral distance and border variables. The distance and border coefficients are not statistically significant. Interestingly, and contrary to the previous results, we do not find a significant impact of the intra-industry trade variable once we include the intra-firm share variable.

\subsection{Intra-national Business Cycle Correlations}

The analysis hereto has shown that foreign affiliates have a positive effect on the synchronization of business cycles between French regions and the countries studied. What about the synchronization of intra-national cycles? The importance of German foreign affiliates in Alsace and in Midi-Pyrénées might well synchronize the GDP growth rates of both regions. We investigate this type of effect in Table 13. In columns 1-4, the business cycle correlation is measured by the correlation of GDP growth rates while in columns 5-8, we use the HPfiltered GDP to compute it. In columns 4 and 8, the specifications include the industrial structure similarity, the distance and the border variables as well as the dissimilarity in the nationality of foreign ownership. All specifications include region-specific effects.

The dissimilarity index (DisFME) enters the specifications negatively and it is significant. In column 4, a 10\% increase in the dissimilarity of foreign ownership reduces the

\footnotetext{
${ }^{26}$ Intra-firm trade information is available only for 1999.
} 
business cycle correlations between French regions by $2.5 \%$ on average. This shows that the nationality of ownership plays a significant role in explaining the synchronization of business cycles. This effect is robust to the inclusion of region fixed effects, but also to the introduction of exogenous components of intra-national cycles, such as bilateral distance and border. Notice that the distance and border variables are insignificant.

In line with Imbs (1999) and Imbs (2004), synchronization appears to be larger in regions that share similar sectoral production patterns. The production structure dissimilarity variable is negative and significant. It is robust across specifications.

\section{Conclusion}

This paper examines the ownership composition of firms within French regions to shed light on the role of foreign affiliates in explaining business cycle comovements. Foreign affiliates are linked to their foreign parents via intra-firm trade, technology transfers, direct investments or their decisions on production. They may thus transmit shocks across borders as long as they contribute largely enough to the economic outcomes of their host region.

Using rich data on the universe of French firms and their activities in France, we establish that the share of majority-owned foreign affiliates is larger among large firms than among smaller ones. Therefore, while there are very few majority-owned foreign affiliates, their contributions to the economic activities of France and its regions are substantial. The data also reveal that the distribution of the activities of foreign affiliates based on their nationality is heterogeneous across French regions. We exploit this to evaluate the role of foreign affiliates in synchronizing intenational business cycles.

We show that the presence of foreign affiliates - either measured through employment, value added, or intra-firm trade intensity - in a region increases the correlation between the fluctuations of the GDP of the region and that of the country of ownership significantly. We also demonstrate that French regions which host foreign affiliates which come from the same countries exhibit greater comovement of GDP growth.

The literature has shown that large firms contribute to aggregate volatility; we show that they also contribute to aggregate co-fluctuations when they are foreign-owned. Our findings thus point to previously unexplored dimensions of the impact of large firms on aggregate outcomes. Since they are important traders, the influence of bilateral trade on business cycle comovements turns out to not be robust. This suggests that multinational linkages are more important that trade linkages.

The nationality and ownership structure of the firms are two dimensions that seem to have important implications for aggregate trade, employment and comovements. One extension of this study that we would consider especially worthwhile is to identify whether the idiosyncratic shocks of multinational firms are specific and important forces explaining these aggregate outcomes. 


\section{References}

Atalay, E., Hortacsu, A. and Syverson, C. (2012), Why do firms own production chains?, Working Paper 18020, National Bureau of Economic Research.

Baxter, M. and Kouparitsas, M. A. (2005), 'Determinants of business cycle comovement: a robust analysis', Journal of Monetary Economics 52(1), 113-157.

Bergin, P. R., Feenstra, R. C. and Hanson, G. H. (2009), 'Offshoring and Volatility: Evidence from Mexico's Maquiladora Industry', American Economic Review 99(4), 1664-71.

Bernard, A. B. and Jensen, J. B. (1997), 'Exporters, skill upgrading, and the wage gap', Journal of International Economics 42(1-2), 3-31.

Bernard, A. B., Jensen, J. B., Redding, S. J. and Schott, P. K. (2010), 'Intrafirm trade and product contractibility', American Economic Review 100(2), 444-48.

Burstein, A., Kurz, C. and Tesar, L. (2008), 'Trade, production sharing, and the international transmission of business cycles', Journal of Monetary Economics 55(4), 775-795.

Calderon, C., Chong, A. and Stein, E. (2007), 'Trade intensity and business cycle synchronization: Are developing countries any different?', Journal of International Economics $71(1), 2-21$.

Clark, T. E. and van Wincoop, E. (2001), 'Borders and business cycles', Journal of International Economics 55(1), 59-85.

Desai, M. A. and Foley, C. F. (2004), The comovement of returns and investment within the multinational firm, Nber working papers, National Bureau of Economic Research, Inc.

di Giovanni, J. and Levchenko, A. A. (2010), 'Putting the Parts Together: Trade, Vertical Linkages, and Business Cycle Comovement', American Economic Journal: Macroeconomics 2(2), 95-124.

di Giovanni, J. and Levchenko, A. A. (2011), Country size, international trade, and aggregate fluctuations in granular economies, NBER Working Papers 17335, National Bureau of Economic Research, Inc.

di Giovanni, J., Levchenko, A. A. and Méjean, I. (2011), Firms, Destinations, and Aggregate Fluctuations, mimeo.

Frankel, J. A. and Rose, A. K. (1998), 'The Endogeneity of the Optimum Currency Area Criteria', Economic Journal 108(449), 1009-25.

Gabaix, X. (2011), 'The granular origins of aggregate fluctuations', Econometrica 79(3), 733772 . 
Goldberg, P. and Hellerstein, R. (2009), How rigid are producer prices?, Working Papers 1184, Princeton University, Department of Economics, Center for Economic Policy Studies.

Helpman, E., ed. (2011), Understanding Global Trade, MA: Harvard University Press.

Hsu, C.-C., Wu, J.-Y. and Yau, R. (2011), 'Foreign direct investment and business cycle co-movements: The panel data evidence', Journal of Macroeconomics 33(4), 770 - 783.

Imbs, J. (2004), 'Trade, Finance, Specialization, and Synchronization', The Review of Economics and Statistics 86(3), 723-734.

Imbs, J. M. (1999), 'Technology, growth and the business cycle', Journal of Monetary Economics 44(1), 65-80.

Inklaar, R., Jong-A-Pin, R. and de Haan, J. (2008), 'Trade and business cycle synchronization in OECD countries-a re-examination', European Economic Review 52(4), 646-666.

Jansen, W. J. and Stokman, A. C. J. (2006), 'International rent sharing and domestic labour markets: A macroeconomic analysis', Review of World Economics (Weltwirtschaftliches Archiv) 142(4), 792-813.

Johnson, R. C. (2011), Trade in Intermediate Inputs and Business Cycle Comovement, mimeo, Dartmouth College.

Kalemli-Ozcan, S., Papaioannou, E. and Peydró, J. L. (2009), Financial regulation, financial globalization and the synchronization of economic activity, NBER Working Papers 14887, National Bureau of Economic Research, Inc.

Kose, M. A. and Yi, K.-M. (2006), 'Can the standard international business cycle model explain the relation between trade and comovement?', Journal of International Economics 68(2), 267-295.

Lipsey, R. E. (2008), Measuring the location of production in a world of intangible productive assets, fdi, and intrafirm trade, Working Paper 14121, National Bureau of Economic Research.

Mansfield, E. (1962), 'Size of firm, market structure, and innovation', Journal of Political Economy $71(6)$.

Mayer, T. and Ottaviano, G. (2008), 'The happy few: The internationalisation of european firms', Intereconomics: Review of European Economic Policy 43(3), 135-148.

Moscarini, G. and Postel-Vinay, F. (2009), Large employers are more cyclically sensitive, NBER Working Papers 14740, National Bureau of Economic Research, Inc.

Ng, E. C. (2010), 'Production fragmentation and business-cycle comovement', Journal of International Economics 82(1), 1-14. 
Ramondo, N. and Rappoport, V. (2010), 'The role of multinational production in a risky environment', Journal of International Economics 81(2), 240-252.

Ramondo, N., Rappoport, V. and Ruhl, K. J. (2011), Horizontal vs. vertical fdi : Revisiting evidence from u.s. multinationals, Technical report.

Ravn, M. O. and Uhlig, H. (2002), 'On adjusting the Hodrick-Prescott filter for the frequency of observations', The Review of Economics and Statistics 84(2), 371-375. 


\section{A Data Appendix}

We build a database that describes value added, employment, and sales in the manufacturing, extractive, agricultural sectors of French regions, as well as their bilateral exports to and imports from 162 partner countries and the value of intra-firm trade. ${ }^{27}$ Within regions, we disentangle activities based on the ownership of firms. Namely, we distinguish activities generated by independent firms, French affiliates, and foreign affiliates (depending on their parent country). The data are matched to a vector of bilateral correlations of business cycles between 21 Metropolitan French regions and these 162 countries. $^{28}$ This dataset is built from the aggregation of several sets of micro-data that are provided by different French administrations.

Firms in France need to report their tax statements (through one of three alternative regimes) to the tax administration. The Bénéfice Réel Normal (BRN) needs to be filed by all firms that have an annual turnover of more than 763,000 euros in manufacturing and more than 230,000 euros in services. Firms with a lower turnover might still opt for the BRN regime, but they are automatically registered under the Regime Simplifié d'Impositions (RSI) instead of the BRN. Firms file for an RSI account for an annual turnover of less than $4 \%$ and a total employment of less than 11\% (see di Giovanni, Levchenko, and Méjean 2011). Entrepreneurs (owner-manager-single-employee firms) with an annual turnover of less than 80,300 euros are subject to the MicroBIC regime, Micro Bénéfice Industriel et Commerciaux. These firms have a negligible weight in the distribution of annual turnover, value added and employment. Of all those regimes, the BRN is the most comprehensive regarding the information available, including balance sheet information on total employment and total value added.

The BRN is merged to "LIFI élargi", a dataset that has information on the ownership and nationality of the parent company of firms located in France. The dataset combines two sources of information. First, a survey on "large" firms that gives detailed information on the ownership of groups, the link between affiliates (at home and abroad), and information on shareholders. Only firms with more than 500 employees, or having a yearly turnover greater than 20 million euros, or having more than 1.2 million euros of shares of other firms are subject to this survey. The survey is completed with DIANE, a dataset that reports financial linkages between firms. Firms with an annual turnover above one million euros are surveyed. Notice that relatively large firms are surveyed, but they indicate their financial links with all their affiliates (if any) irrespective of their size. Furthermore, the sample of firms that are surveyed (the ones with more than 500 employees or more than 1 million euros of turnover) represents half of the firms, but these firms account for $94 \%$ of total value added.

We classify firms according to their nationality and ownership. We denote by IND (for independent), French domestic firms, which are located in France and not owned by a group. A French affiliate, MNE, is located in France and owned by a French group. We denote by

\footnotetext{
${ }^{27}$ We do not have information on services.

${ }^{28}$ We exclude the comovement between French regions and France as a whole.
} 
FME foreign affiliates, which are located in France and owned by a foreign group. Later on, we will distinguish the foreign affiliates based on their nationality. At this stage, our data consists of an exhausitve panel of 184,929 firms, for the 1999-2004 period.

We merge the data with a dataset provided by French Customs that gives information on bilateral exports and imports of firms located in France. For each firm, this database reports the bilateral free-on-board value, the quantity of exports, the cost-insurance-freight value and the quantity of imports. Extra-European shipments of a value which is less than 1,000 euros are subject to a simplified declaration procedure and do not appear in our data. Within the Single European Market, the reporting threshold is based on the cumulated yearly export value of each firm (all destinations within the EU). This threshold has increased over time, up to 100,000 euros in 2002 and 150,00 euros in 2003.

Information on intra-firm trade is taken from the EIIG firm-level survey (Échanges Internationaux Intra-Groupe.) The data are provided by INSEE (Institut National de la Statistique et de Etudes Economiques) and are only available for 1999. The survey was addressed to all French firms whose value of trade was over 1 million euros, owned by groups that controlled at least $50 \%$ of the equity capital of a foreign affiliate. It provides a detailed geographical breakdown of the import and export value of French firms at product level (HS4) and their sourcing modes - outsourcing and/or intra-firm trade.

We aggregate the firm-level data at the regional level. A firm located in France might have several plants in different regions. When it comes to filing the BRN or the Customs' forms, the value added, sales or trade values are always allocated to the region of the headquarters of the multi-plant firm. In order to compute the regional GDP, the INSEE reallocates the value added of multi-plant firms based on the share of employment made by plants in each region. Each plant is recorded in a dataset called STOJAN that has limited plant-level information, mostly on its employment and its identifier. The identifier of the plant is such that it can be easily merged to the identifier of the firm. We use STOJAN to reallocate the value added, sales and trade of multi-plant firm. In our sample, only $1.8 \%$ of firms are multi-plant and multi-region. Yet these firms account for $9.8 \%$ of total employment. ${ }^{29} \mathrm{We}$ are now able to aggregate the statistics at the level of each of the 21 Metropolitan regions.

This database at the regional level is then combined with a dataset that contains the correlation of the business cycles between a French region $i$ and a partner country $c$. We consider 162 partner countries over the 1990-2006 period. The correlation of the cycles between region $i$ and country $c$ is computed as the correlation in the annual growth rates or the correlation of HP-filtered GDPs.

As a measure of regional GDP, we use the publicly available GDP computed by INSEE over the 1990-2006 period. We combine it with World Bank data for the GDP of countries, in current US dollars. While the GDP of the countries are in dollars, the French regional GDPs are in euros. We convert the GDP of the countries into euros using the EUR-USD exchange rate given by Eurostat. The database is completed with the total exports and imports of the partner countries that we take from the Direction Of Trade Statistics (DOTS).

\footnotetext{
${ }^{29}$ We have access to this data for the $1999-2004$ period.
} 


\section{B Figures}

Figure 1: Ownership breakdown of the top $1 \%$ firms in terms of value added, by French region

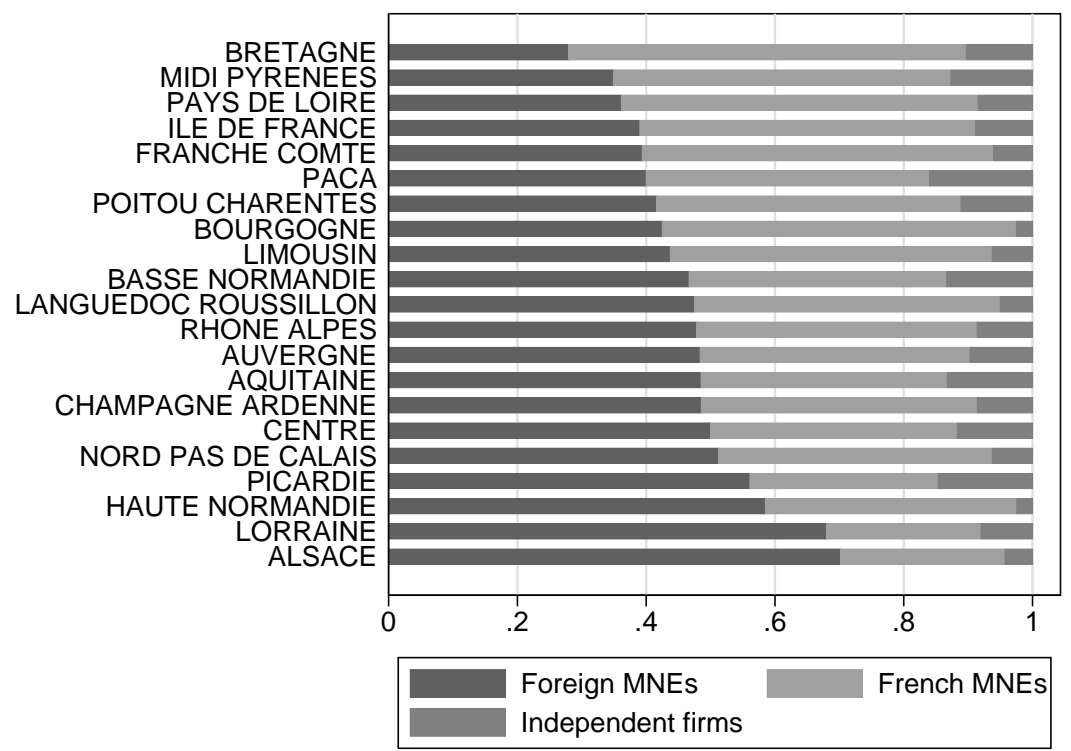

This figure presents the (average over 1999-2004) ownership structure of the 1\%largest firms (in terms of value added), for each French region. Three ownership structures are distinguished: independent French firms, French multinational firms, and foreign multinational firms. The figure is based on the authors' computations relying on 3 datasets: BRN, STOJAN, and LIFI. The results stand for manufacturing, extractive, and agriculture industries. 
Figure 2: Dissecting the rest... the $99 \%$ of small firms, by French region

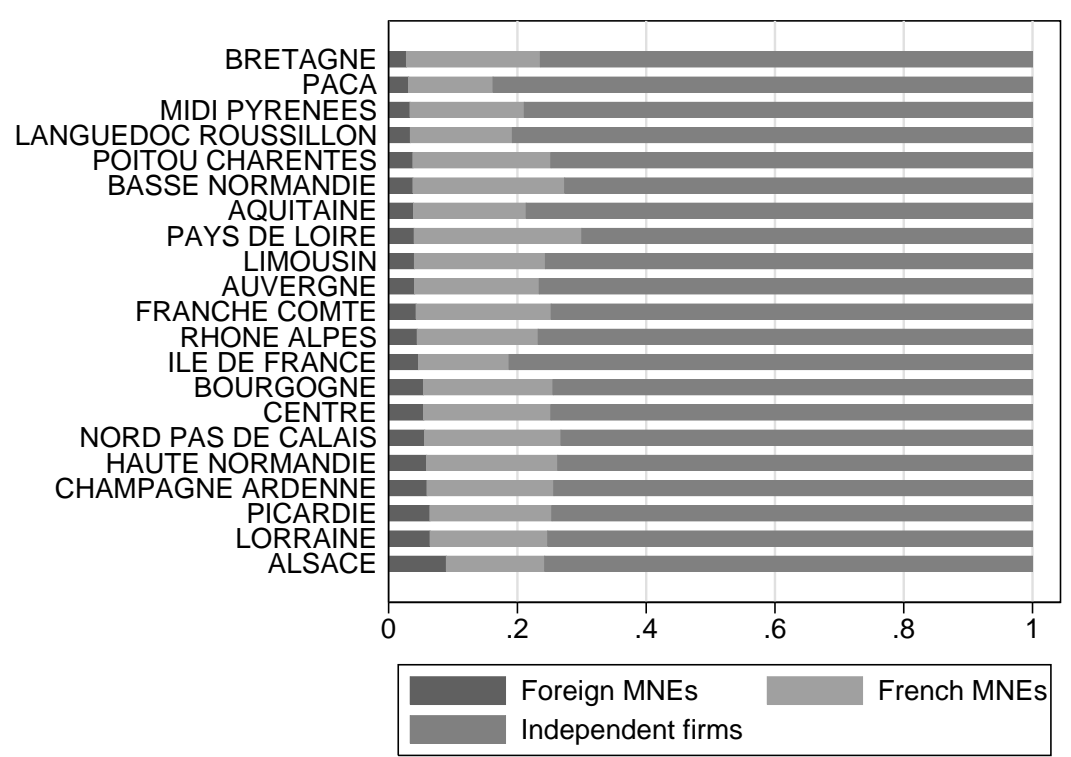

This figure presents the (average over 1999-2004) ownership structure of the firms smaller than the 1\%largest firms (in terms of value added), for each French region. Three ownership structures are distinguished: independent French firms, French multinational firms, and foreign multinational firms. The figure is based on the authors' computations relying on 3 datasets: BRN, STOJAN, and LIFI. The results stand for manufacturing, extractive, and agriculture industries. 
Figure 3: Ranking of the foreign affiliates among the 500 largest firms, by French region

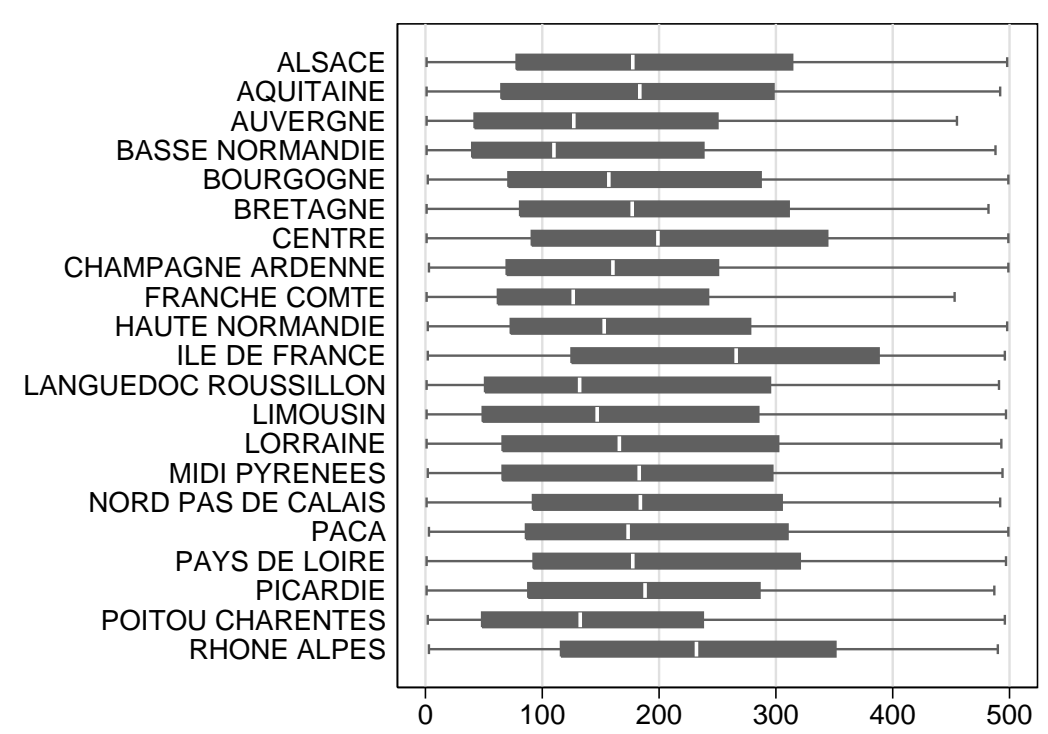

This figure presents the ranking distribution of foreign affiliates among the largest 500 firms, for each French region. The results stand for manufacturing, extractive, and agriculture industries. 
Figure 4: Share of foreign affiliates in regional value added (manufacturing extractive, and agriculture industries), by country of origin of the parent, 2004 (\% total)

(a) Japan

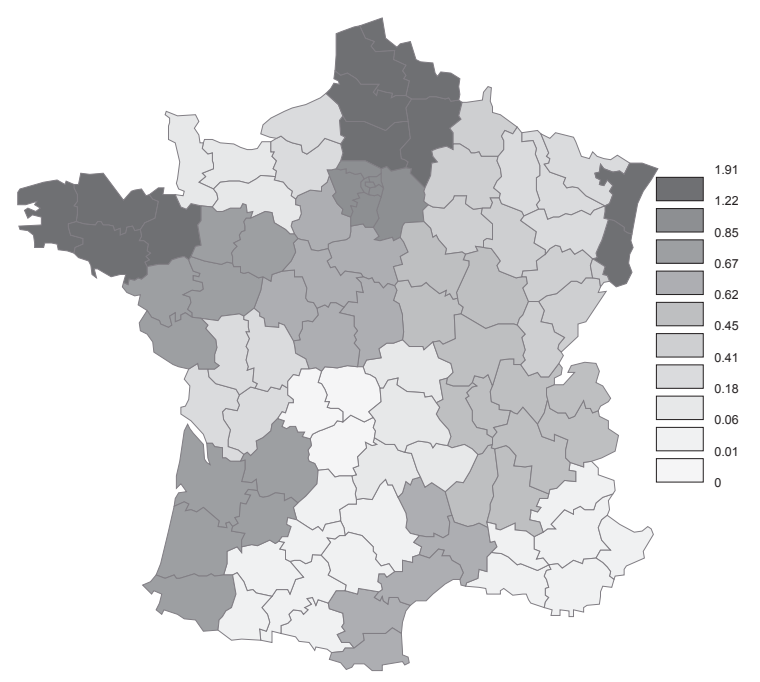

(c) Germany

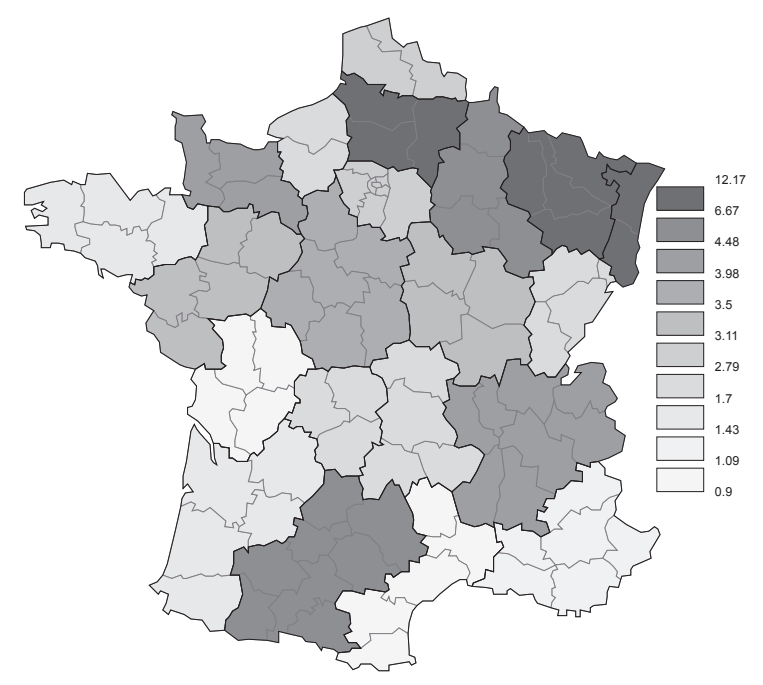

(b) USA

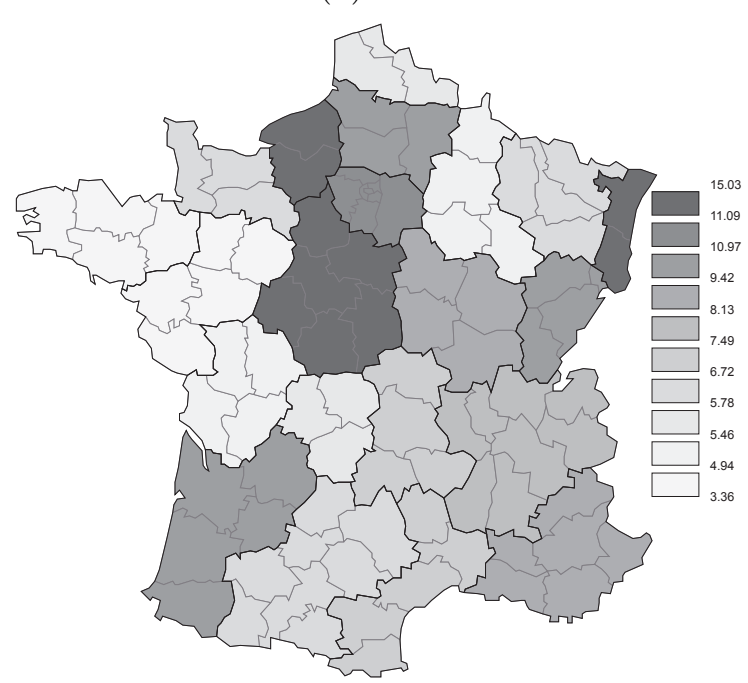

(d) Spain

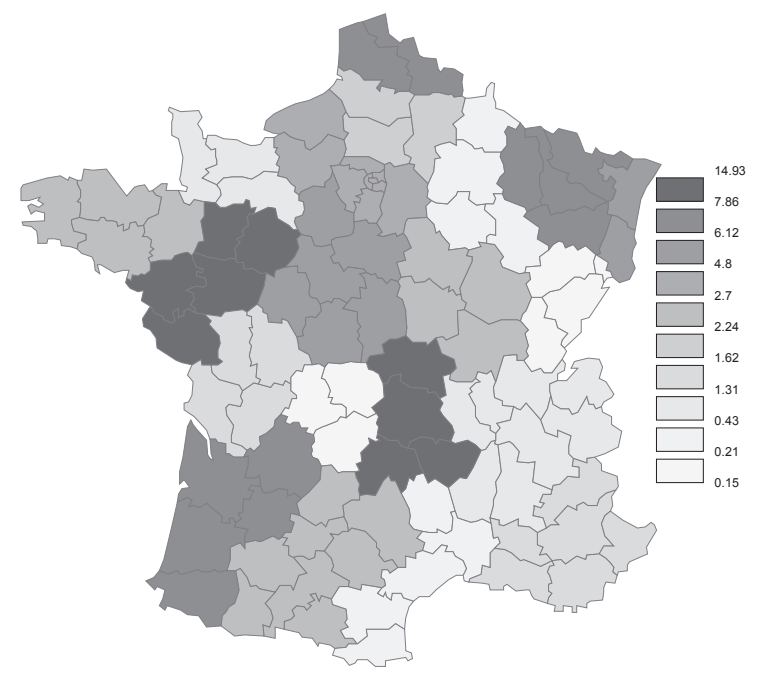


C Tables 


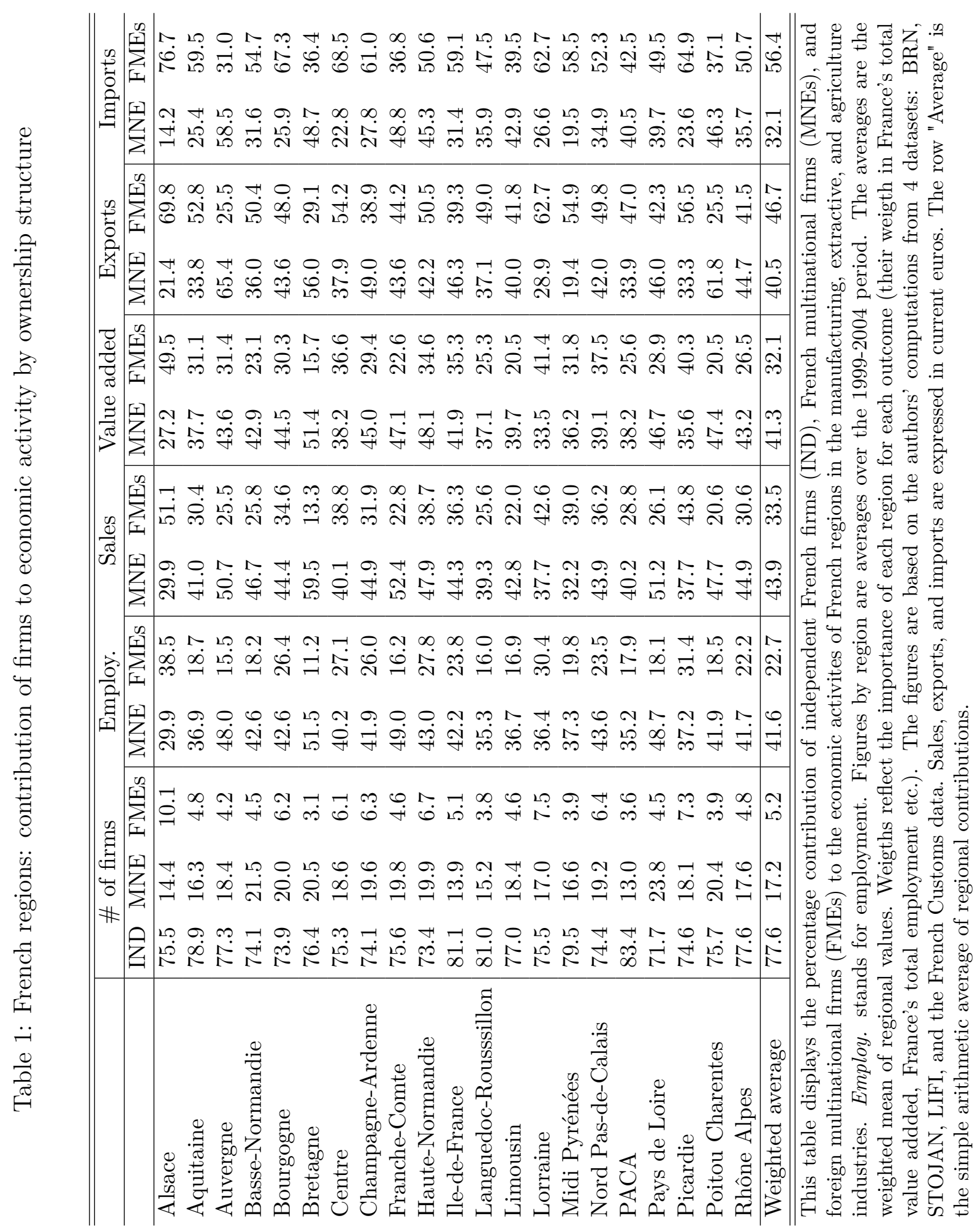




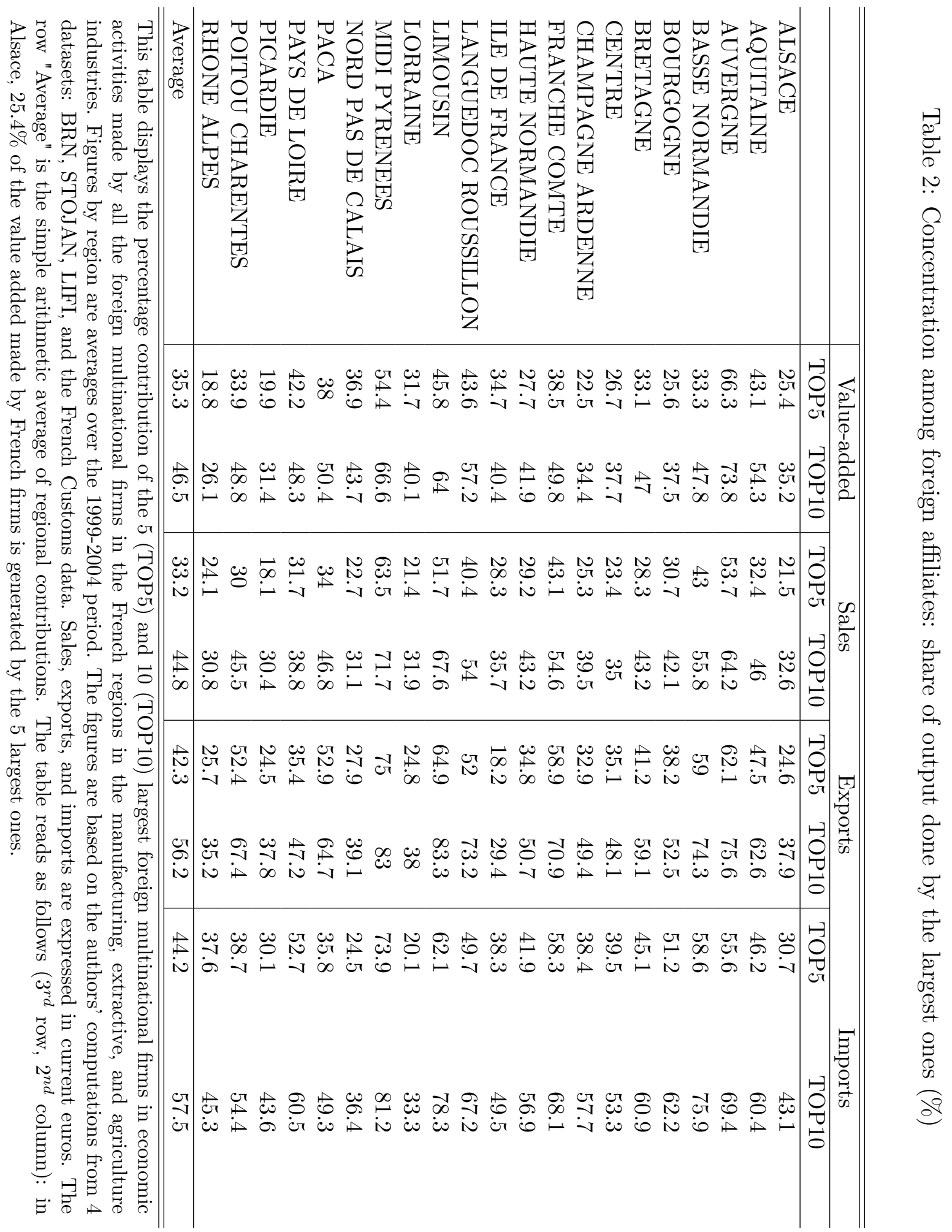




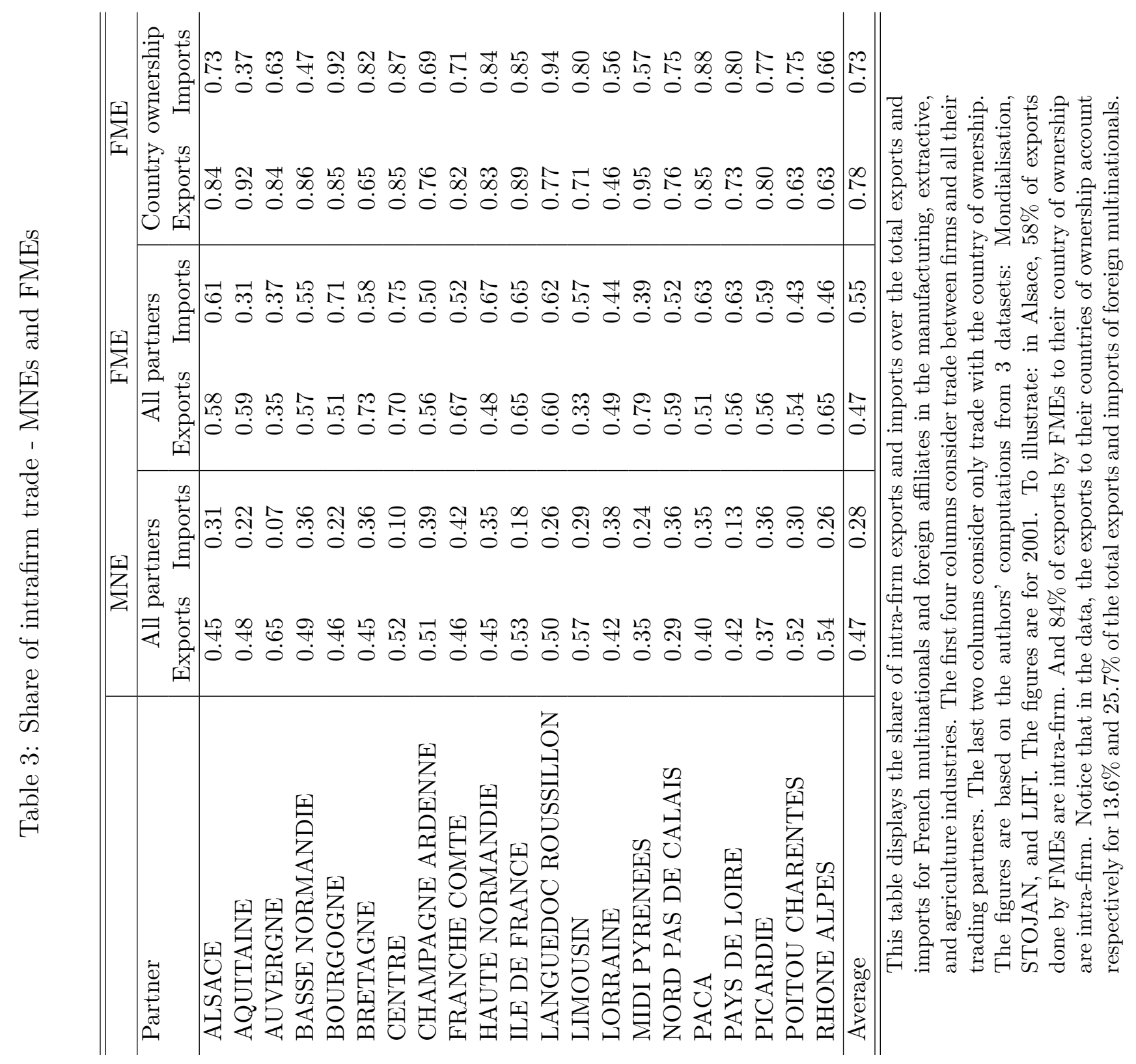


Table 4: Comovement between French regions: selected minima and maxima

\begin{tabular}{cc}
\hline \hline 5 Highest & Corr. \\
\hline Lorraine / Poitou-Charentes & 0.89 \\
Pays de Loire / Centre & 0.88 \\
Pays de Loire / Franche-Comté & 0.86 \\
Pays de Loire / Haute-Normandie & 0.88 \\
Bourgogne / Poitou-Charentes & 084 \\
\hline \hline 5 Lowest & Corr. \\
\hline Midi-Pyrénées / Champagne-Ardennes & -0.07 \\
Midi-Pyrénées / Alsace & 0.01 \\
Île-de-France / Champagne-Ardennes & 0.07 \\
Île-de-France / Lorraine & 0.07 \\
Île-de-France / Midi-Pyrénées & 0.1 \\
\hline \hline
\end{tabular}

This table displays the 5 largest and 5 smallest levels of correlation of business cycles among French regions for the 1999-2006 period. The business cycle correlation is computed as the correlation of GDP growth between French regions. The regional GDP data are from the INSEE. 
Table 5: Comovement between French regions and selected countries: extrema.

\begin{tabular}{|c|c|c|c|}
\hline \multicolumn{4}{|c|}{ Germany } \\
\hline 3 Highest & & 3 Lowest & \\
\hline Alsace & 0.39 & Languedoc-Roussillon & -0.138 \\
\hline Lorraine & 0.36 & Île-de-France & -0.21 \\
\hline Picardie & 0.35 & Auvergne & -0.29 \\
\hline \multicolumn{4}{|c|}{ Spain } \\
\hline 3 Highest & & 3 Lowest & \\
\hline Languedoc-Roussillon & 0.62 & Franche-Comté & 0.20 \\
\hline Limousin & 0.61 & Champagne-Ardenne & 0.19 \\
\hline Rhône-Alpes & 0.60 & Alsace & 0.062 \\
\hline \multicolumn{4}{|c|}{ USA } \\
\hline 3 Highest & & 3 Lowest & \\
\hline Île-de-France & 0.36 & Centre & -0.30 \\
\hline Aquitaine & 0.20 & Picardie & -0.31 \\
\hline Bretagne & 0.18 & Nord-Pas-de-Calais & -0.32 \\
\hline \multicolumn{4}{|c|}{ Japan } \\
\hline 3 Highest & & 3 Lowest & \\
\hline Île-de-France & 0.18 & Picardie & -0.34 \\
\hline Basse-Normandie & 0.11 & Auvergne & -0.45 \\
\hline Haute-Normandie & 0.066 & Nord-Pas-de-Calais & -0.48 \\
\hline
\end{tabular}

This table displays the 3 lowest and 3 highest levels of correlation of business cycles between French regions and 6 selected countries. The business cycle correlation is computed as the correlation of GDP growth of French regions and foreign countries. The regional GDP data are from the INSEE. The country GDPs are USD GDPs from IFS, converted into euros using Compustat data. 
Table 6: Summary Statistics

\begin{tabular}{|c|c|c|c|c|}
\hline Variable & Label & Obs & Mean & $\begin{array}{l}\text { Std. } \\
\text { Dev. }\end{array}$ \\
\hline \multicolumn{5}{|l|}{ International Business Cycle Approach } \\
\hline$\overline{\text { Correlation of GDP growth rate }}$ & $\rho_{r c}$ & 3329 & 0.047 & 0.241 \\
\hline Correlation of HP-filtered GDP & $\rho_{r c}$ & 3329 & 0.082 & 0.251 \\
\hline Foreign Value Added Share & $F M E_{c r}$ & 3329 & $3.10^{-4}$ & 0.002 \\
\hline Foreign Employment Share & $F M E_{c r}(E m p l)$. & 3329 & $2.10^{-4}$ & 0.001 \\
\hline Bilateral Trade & $B T_{c r}$ & 3329 & $2.10^{-4}$ & 0.001 \\
\hline Distance & Distance $_{c r}$ & 3329 & 7.935 & 0.823 \\
\hline Intra-Industry Trade & $I I T_{c r}$ & 3329 & 0.036 & 0.087 \\
\hline Border & Border $_{c r}$ & 3329 & 0.003 & 0.057 \\
\hline Intra-Firm Trade & $I F_{c r}$ & 3276 & 0.003 & 0.041 \\
\hline \multicolumn{5}{|l|}{ Intra-national Business Cycle Approach } \\
\hline Correlation of Regions' GDP growth rate & $\rho_{r r^{\prime}}$ & 0.53 & 0.18 & 210 \\
\hline Correlation of Regions' HP-filtered GDP & $\rho_{r r^{\prime}}$ & 0.51 & 0.19 & 210 \\
\hline Dissimilarity of nationality of ownership (log) & DisF $M E_{r r^{\prime}}$ & 4.3 & 0.35 & 210 \\
\hline Dissimilarity of economic structure (log) & $S_{r r^{\prime}}$ & -1.94 & 0.58 & 210 \\
\hline Distance $(\log )$ & Dist & 6.12 & 0.48 & 210 \\
\hline
\end{tabular}




\section{Tables: Regressions}

Table 7: Foreign Affiliates and Business Cycle Correlations

\begin{tabular}{|c|c|c|c|c|c|}
\hline \multicolumn{6}{|c|}{ Dependent variable: $\rho_{c r}=$ Correlation of growth rate of GDPs } \\
\hline$F M E_{c r}$ (Empl.) & $\begin{array}{c}12.715^{a} \\
(4.05)\end{array}$ & & $\begin{array}{c}11.014^{a} \\
(3.43)\end{array}$ & $\begin{array}{c}10.945^{a} \\
(3.43)\end{array}$ & $\begin{array}{c}10.265^{a} \\
(3.02)\end{array}$ \\
\hline$B T_{c r}$ & & $\begin{array}{c}20.420^{a} \\
(2.68)\end{array}$ & $\begin{array}{c}15.362^{c} \\
(1.95)\end{array}$ & $\begin{array}{c}13.433^{c} \\
(1.71)\end{array}$ & $\begin{array}{l}11.312 \\
(1.35)\end{array}$ \\
\hline$I I T_{c r}$ & & & & $\begin{array}{l}0.072^{c} \\
(1.69)\end{array}$ & $\begin{array}{l}0.070 \\
(1.64)\end{array}$ \\
\hline Border $_{c r}$ & & & & & $\begin{array}{l}0.006 \\
(0.09)\end{array}$ \\
\hline Distance $_{c r}$ & & & & & $\begin{array}{l}-0.023 \\
(-0.90)\end{array}$ \\
\hline Region FE & Yes & Yes & Yes & Yes & Yes \\
\hline Country FE & Yes & Yes & Yes & Yes & Yes \\
\hline Observations & 3402 & 3402 & 3402 & 3329 & 3329 \\
\hline$R^{2}$ & 0.691 & 0.690 & 0.691 & 0.693 & 0.693 \\
\hline
\end{tabular}

This table investigates the determinants of the bilateral comovement of business cycles between French regions and foreign GDPs. The comovement is measured by the correlation of the yearly growth of region $r$ and country $c$ GDPs over the 1990-2006 period. The explanatory variables are the share of employment $\left(F M E_{c r}\right)$ made by foreign affiliates from country $c$ in region $r$, the bilateral trade $\left(B T_{c r}\right)$ between region $r$ and country $c$, normalized by the two GDPS, the share of intra-industry trade $\left(I I T_{c r}\right)$ between region $r$ and country $c$, the bilateral distance, and a dummy equal to one for contiguous region-country pairs. All regressions include region and country fixed effects. Robust t-statistics are reported between parentheses. ${ }^{c},{ }^{b}$, and ${ }^{a}$ indicate significance at 10,5 , and 1 percent levels. 
Table 8: Foreign Affiliates and Business Cycle Correlations (yearly estimate)

\begin{tabular}{|c|c|c|c|c|c|c|}
\hline \multicolumn{7}{|c|}{ Dependent variable: $\rho_{c r}=$ Correlation of growth rate of GDPs } \\
\hline Year & 1999 & 2000 & 2001 & 2002 & 2003 & 2004 \\
\hline$F M E_{c r}$ (Empl.) & $\begin{array}{l}11.413^{a} \\
(3.596)\end{array}$ & $\begin{array}{l}11.666^{a} \\
(3.876)\end{array}$ & $\begin{array}{l}10.215^{a} \\
(3.454)\end{array}$ & $\begin{array}{l}9.780^{a} \\
(3.373)\end{array}$ & $\begin{array}{l}10.333^{a} \\
(3.181)\end{array}$ & $\begin{array}{l}10.265^{a} \\
(3.015)\end{array}$ \\
\hline$B T_{c r}$ & $\begin{array}{l}-2.890 \\
(-0.304)\end{array}$ & $\begin{array}{l}-0.020 \\
(-0.003)\end{array}$ & $\begin{array}{c}5.060 \\
(0.712)\end{array}$ & $\begin{array}{c}6.098 \\
(0.842)\end{array}$ & $\begin{array}{l}12.330 \\
(1.414)\end{array}$ & $\begin{array}{l}11.312 \\
(1.348)\end{array}$ \\
\hline$I I T_{c r}$ & $\begin{array}{c}0.084^{c} \\
(1.927)\end{array}$ & $\begin{array}{c}0.079^{c} \\
(1.834)\end{array}$ & $\begin{array}{c}0.072^{c} \\
(1.684)\end{array}$ & $\begin{array}{c}0.071^{c} \\
(1.661)\end{array}$ & $\begin{array}{c}0.066 \\
(1.545)\end{array}$ & $\begin{array}{c}0.070 \\
(1.643)\end{array}$ \\
\hline Border $_{c r}$ & $\begin{array}{c}0.023 \\
(0.382)\end{array}$ & $\begin{array}{c}0.015 \\
(0.246)\end{array}$ & $\begin{array}{c}0.011 \\
(0.174)\end{array}$ & $\begin{array}{c}0.010 \\
(0.156)\end{array}$ & $\begin{array}{c}0.003 \\
(0.041)\end{array}$ & $\begin{array}{c}0.006 \\
(0.089)\end{array}$ \\
\hline Distance $_{c r}$ & $\begin{array}{l}-0.032 \\
(-1.211)\end{array}$ & $\begin{array}{c}-0.033 \\
(-1.286)\end{array}$ & $\begin{array}{c}-0.027 \\
(-1.054)\end{array}$ & $\begin{array}{l}-0.028 \\
(-1.085)\end{array}$ & $\begin{array}{c}-0.023 \\
(-0.893)\end{array}$ & $\begin{array}{c}-0.023 \\
(-0.901)\end{array}$ \\
\hline Region FE & Yes & Yes & Yes & Yes & Yes & Yes \\
\hline Country FE & Yes & Yes & Yes & Yes & Yes & Yes \\
\hline $\begin{array}{l}\text { Obs. } \\
R^{2}\end{array}$ & $\begin{array}{l}3,329 \\
0.693\end{array}$ & $\begin{array}{l}3,329 \\
0.693\end{array}$ & $\begin{array}{l}3,329 \\
0.693\end{array}$ & $\begin{array}{l}3,329 \\
0.693\end{array}$ & $\begin{array}{l}3,329 \\
0.693\end{array}$ & $\begin{array}{l}3,329 \\
0.693\end{array}$ \\
\hline
\end{tabular}

This table investigates the determinants of the bilateral comovement of business cycles between French regions and foreign GDPs. The comovement is measured by the correlation of the yearly growth of region $r$ and country $c$ GDPs over the 1990-2006 period. The explanatory variables are the share of employment $\left(F M E_{c r t}\right)$ made by foreign affiliates from country $c$ in region $r$ at period $t$, the bilateral trade $\left(B T \_c r\right)$ between region $r$ and country $c$, normalized by the two GDPS, the share of intra-industry trade (IIT_cr) between region $r$ and country $c$, the bilateral distance, and a dummy equal to one for contiguous region-country pairs. All regressions include region and country fixed effects. Robust t-statistics are reported between parentheses. ${ }^{c},{ }^{b}$, and ${ }^{a}$ indicate significance at 10, 5 , and 1 percent levels. 
Table 9: Foreign Affiliates and Business Cycle Correlations (HP-filtered GDPs)

\begin{tabular}{|c|c|c|c|c|c|}
\hline \multicolumn{6}{|c|}{ Dependent variable: $\rho_{c r}=$ Correlation of HP-filtered GDPs } \\
\hline & $(1)$ & $(2)$ & $(3)$ & $(4)$ & $(5)$ \\
\hline$F M E \_c r($ Empl.) & $\begin{array}{l}6.971^{b} \\
(2.32)\end{array}$ & & $\begin{array}{l}5.614^{c} \\
(1.84)\end{array}$ & $\begin{array}{l}5.347^{c} \\
(1.76)\end{array}$ & $\begin{array}{l}5.760^{c} \\
(1.68)\end{array}$ \\
\hline$B T_{\_} c r$ & & $\begin{array}{c}14.830^{c} \\
(1.86)\end{array}$ & $\begin{array}{c}12.252 \\
(1.50)\end{array}$ & $\begin{array}{l}9.559 \\
(1.18)\end{array}$ & $\begin{array}{l}8.828 \\
(1.05)\end{array}$ \\
\hline$I I T \_c r$ & & & & $\begin{array}{l}0.092^{c} \\
(1.94)\end{array}$ & $\begin{array}{l}0.089^{c} \\
(1.87)\end{array}$ \\
\hline Border_cr & & & & & $\begin{array}{l}-0.054 \\
(-0.73)\end{array}$ \\
\hline Distance_cr & & & & & $\begin{array}{l}-0.032 \\
(-1.12)\end{array}$ \\
\hline Region FE & Yes & Yes & Yes & Yes & Yes \\
\hline Country FE & Yes & Yes & Yes & Yes & Yes \\
\hline Observations & 3402 & 3402 & 3402 & 3329 & 3329 \\
\hline$R^{2}$ & 0.663 & 0.663 & 0.663 & 0.665 & 0.693 \\
\hline
\end{tabular}

This table investigates the determinants of the bilateral comovement of business cycles between French regions and foreign GDPs. The comovement is measured by the correlation of the HP-filtered GDPs of region $r$ and country $c$, over the 1990-2006 period. The explanatory variables are the share of employment $\left(F M E_{c r}\right)$ made by foreign affiliates from country $c$ in region $r$, the bilateral trade $\left(B T_{c r}\right)$ between region $r$ and country $c$, normalized by the two GDPs, the share of intra-industry trade $\left(I I T_{c r}\right)$ between region $r$ and country $c$, the bilateral distance, and a dummy equal to one for contiguous region-country pairs. All regressions include region and country fixed effects. Robust t-statistics are reported between parentheses. ${ }^{c},{ }^{b}$, and ${ }^{a}$ indicate significance at 10,5 , and 1 percent levels. 
Table 10: Intra-Firm Trade and Business Cycle Correlations

\begin{tabular}{|c|c|c|c|c|c|}
\hline \multicolumn{6}{|c|}{ Dependent variable: $\rho_{\text {cr }}=$ Correlation of growth rate of GDP } \\
\hline$I F_{c r}$ & $\begin{array}{c}0.289^{a} \\
(3.89)\end{array}$ & & $\begin{array}{c}0.257^{a} \\
(3.69)\end{array}$ & $\begin{array}{r}0.252^{a} \\
(3.59)\end{array}$ & $\begin{array}{c}0.249^{a} \\
(3.43)\end{array}$ \\
\hline$B T_{c r}$ & & $\begin{array}{c}20.420^{a} \\
(2.68)\end{array}$ & $\begin{array}{c}15.906^{b} \\
(2.14)\end{array}$ & $\begin{array}{c}14.085^{c} \\
(1.90)\end{array}$ & $\begin{array}{l}11.772 \\
(1.47)\end{array}$ \\
\hline$I I T_{c r}$ & & & & $\begin{array}{l}0.069 \\
(1.62)\end{array}$ & $\begin{array}{l}0.067 \\
(1.55)\end{array}$ \\
\hline Border $_{c r}$ & & & & & $\begin{array}{l}-0.011 \\
(-0.16)\end{array}$ \\
\hline Distance $_{c r}$ & & & & & $\begin{array}{l}-0.031 \\
(-1.18)\end{array}$ \\
\hline Region FE & Yes & Yes & Yes & Yes & Yes \\
\hline Country FE & Yes & Yes & Yes & Yes & Yes \\
\hline Observations & 3298 & 3402 & 3298 & 3276 & 3276 \\
\hline$R^{2}$ & 0.692 & 0.690 & 0.693 & 0.693 & 0.693 \\
\hline
\end{tabular}

This table investigates the determinants of the bilateral comovement of business cycles between French regions and foreign GDPs. The comovement is measured by the correlation of the yearly growth of region $r$ and country $c$ GDPs over the 1990-2006 period. The explanatory variables are the ratio of intra-firm trade $\left(I F_{c r}\right)$ with country $c$ made by foreign affiliates from country $c$ in located region $r$ over the region's GDP, the bilateral trade $\left(B T_{c r}\right)$ between region $r$ and country $c$, normalized by the two GDPs, the share of intra-industry trade $\left(I I T_{c r}\right)$ between region $r$ and country $c$, the bilateral distance, and a dummy equal to one for contiguous region-country pairs. All regressions include region and country fixed effects. Robust tstatistics are reported between parentheses. ${ }^{c},{ }^{b}$, and ${ }^{a}$ indicate significance at 10,5 , and 1 percent levels. 
Table 11: Intra-Firm Trade and Business Cycle Correlations (HP-filtered GDPs)

\begin{tabular}{|c|c|c|c|c|c|}
\hline \multicolumn{6}{|c|}{$\begin{array}{l}\text { Dependent variable: } \rho_{c r}=\text { Correlation of HP-Filtered GDPs } \\
(1)\end{array}$} \\
\hline$I F_{c r}$ & $\begin{array}{l}0.177^{b} \\
(2.28)\end{array}$ & & $\begin{array}{l}0.154^{b} \\
(2.05)\end{array}$ & $\begin{array}{l}0.147^{c} \\
(1.96)\end{array}$ & $\begin{array}{l}0.174^{b} \\
(2.10)\end{array}$ \\
\hline$B T_{c r}$ & & $\begin{array}{c}14.830^{c} \\
(1.86)\end{array}$ & $\begin{array}{l}11.811 \\
(1.49)\end{array}$ & $\begin{array}{l}9.415 \\
(1.19)\end{array}$ & $\begin{array}{l}8.839 \\
(1.09)\end{array}$ \\
\hline$I I T_{c r}$ & & & & $\begin{array}{l}0.089^{c} \\
(1.89)\end{array}$ & $\begin{array}{l}0.085^{c} \\
(1.80)\end{array}$ \\
\hline Border $_{c r}$ & & & & & $\begin{array}{l}-0.071 \\
(-0.90)\end{array}$ \\
\hline Distance $_{c r}$ & & & & & $\begin{array}{l}-0.036 \\
(-1.24)\end{array}$ \\
\hline Region FE & Yes & Yes & Yes & Yes & Yes \\
\hline Country FE & Yes & Yes & Yes & Yes & Yes \\
\hline Observations & 3298 & 3402 & 3298 & 3276 & 3276 \\
\hline$R^{2}$ & 0.665 & 0.663 & 0.665 & 0.665 & 0.666 \\
\hline
\end{tabular}

This table investigates the determinants of the bilateral comovement of business cycles between French regions and foreign GDPs. The comovement is measured by the correlation of region $r$ and country $c$ HP-filtered yearly GDPs over the 1990-2006 period. The explanatory variables are the ratio of intra-firm trade $\left(I F_{c r}\right)$ with country $c$ made by foreign affiliates from country $c$ in located region $r$ over the region's GDP, the bilateral trade $\left(B T_{c r}\right)$ between region $r$ and country $c$, normalized by the two GDPs, the share of intra-industry trade $\left(I I T_{c r}\right)$ between region $r$ and country $c$, the bilateral distance, and a dummy equal to one for contiguous region-country pairs. All regressions include region and country fixed effects. Robust tstatistics are reported between parentheses. ${ }^{c},{ }^{b}$, and ${ }^{a}$ indicate significance at 10,5 , and 1 percent levels. 
Table 12: Similarity of Nationalities of Ownership and Business Cycle Correlation of French Regions

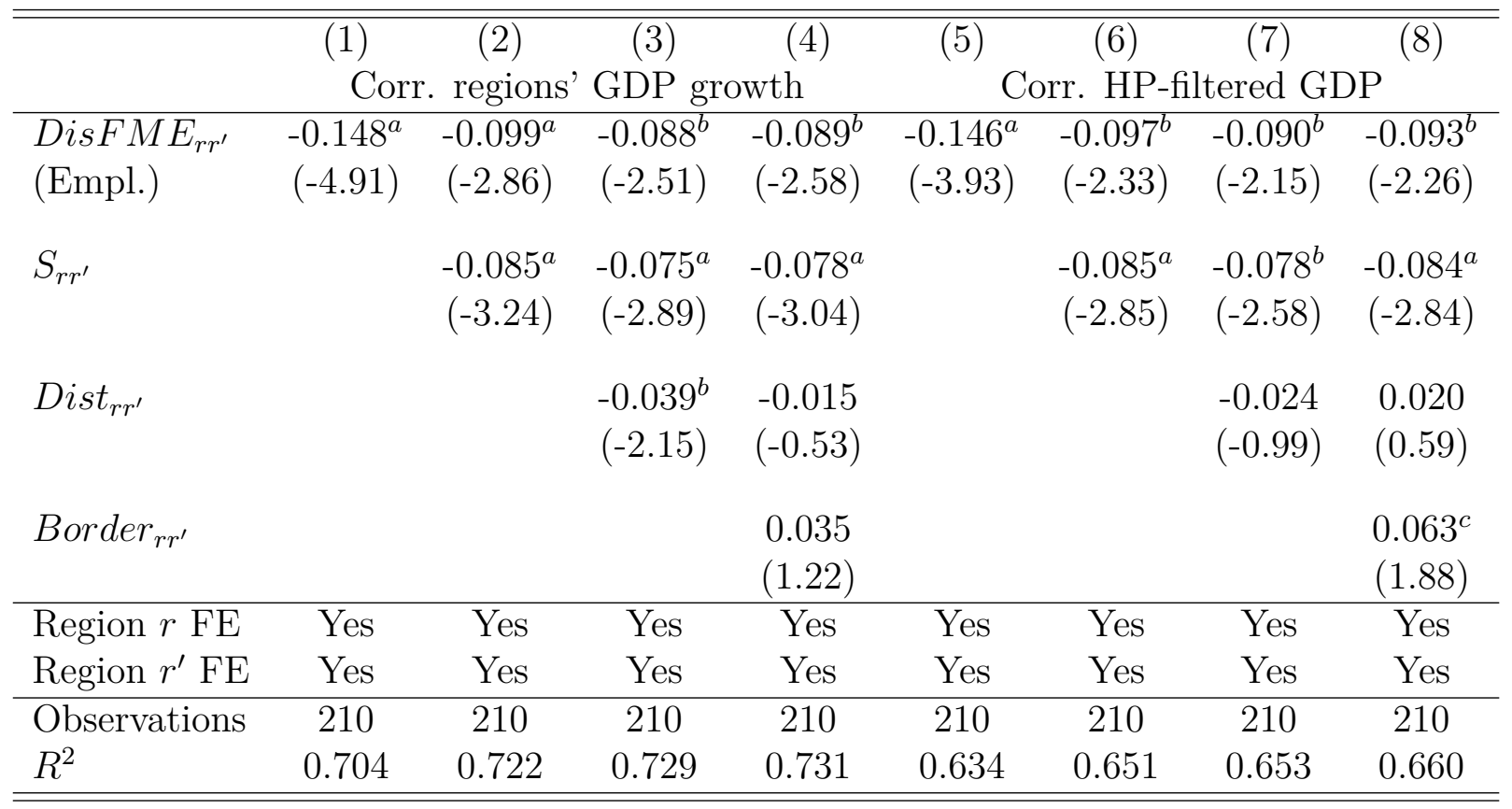

This table investigates the impact of dissimilarity in the nationality of foreign affiliates between French regions on the bilateral correlation of business cycles across regions. In columns 1-4, the explained variable is the bilateral correlation of GDP growth across regions. In columns 5-8, the explained variable is the bilateral correlation of HP-filtered GDPs. DisFME $E_{r r^{\prime}}$ (Empl.) measures the dissimilarity in the nationality of foreign affiliates for region pairs in terms of employment presence. $S_{r r^{\prime}}$ measures the dissimilarity in the economic structure of region pairs. Dist $t_{r r^{\prime}}$ is a measure of the bilateral distance between regions. Border $r_{r}$ is a dummy equal to one if region pairs share a common border. Two sets of region fixed effects are introduced in all the regressions. Robust standard errors are reported. ${ }^{c},{ }^{b}$, and ${ }^{a}$ indicate significance at 10,5 , and 1 percent levels. 
Table 13: Similarity of Nationalities of Ownership and Business Cycle Correlation of French Regions

\begin{tabular}{|c|c|c|c|c|c|c|c|c|}
\hline & (1) & (2) & $(3)$ & $(4)$ & $(5)$ & $(6)$ & $(7)$ & $(8)$ \\
\hline & \multicolumn{4}{|c|}{ Corr. regions' GDP growth } & \multicolumn{4}{|c|}{ Corr. HP-filtered GDP } \\
\hline$\overline{D i s F M E_{r r^{\prime}}}$ & $\begin{array}{c}-0.202^{a} \\
(5.58)\end{array}$ & $\begin{array}{c}-0.136^{a} \\
(3.18)\end{array}$ & $\begin{array}{c}-0.126^{a} \\
(3.00)\end{array}$ & $\begin{array}{c}-0.129^{a} \\
(3.10)\end{array}$ & $\begin{array}{c}-0.183^{a} \\
(4.06)\end{array}$ & $\begin{array}{c}-0.111^{b} \\
(2.08)\end{array}$ & $\begin{array}{c}-0.105^{c} \\
(1.97)\end{array}$ & $\begin{array}{c}-0.109^{b} \\
(2.11)\end{array}$ \\
\hline$S_{r r^{\prime}}$ & & $\begin{array}{r}-0.081^{a} \\
(2.98)\end{array}$ & $\begin{array}{r}-0.067^{b} \\
(2.53)\end{array}$ & $\begin{array}{c}-0.070^{b} \\
(2.67)\end{array}$ & & $\begin{array}{c}-0.088^{a} \\
(2.74)\end{array}$ & $\begin{array}{c}-0.079^{b} \\
(2.43)\end{array}$ & $\begin{array}{r}-0.084^{b} \\
(2.66)\end{array}$ \\
\hline Dist $_{r r^{\prime}}$ & & & $\begin{array}{c}-0.044^{b} \\
(2.41)\end{array}$ & $\begin{array}{l}-0.019 \\
(0.69)\end{array}$ & & & $\begin{array}{l}-0.030 \\
(1.23)\end{array}$ & $\begin{array}{l}0.014 \\
(0.42)\end{array}$ \\
\hline Border $_{r r^{\prime}}$ & & & & $\begin{array}{c}0.036 \\
(1.31)\end{array}$ & & & & $\begin{array}{l}0.064^{c} \\
(1.91)\end{array}$ \\
\hline Region $r$ FE & Yes & Yes & Yes & Yes & Yes & Yes & Yes & Yes \\
\hline Region $r^{\prime} \mathrm{FE}$ & Yes & Yes & Yes & Yes & Yes & Yes & Yes & Yes \\
\hline Observations & 210 & 210 & 210 & 210 & 210 & 210 & 210 & 210 \\
\hline$R^{2}$ & 0.707 & 0.723 & 0.731 & 0.734 & 0.629 & 0.646 & 0.649 & 0.657 \\
\hline
\end{tabular}

This table investigates the impact of dissimilarity in the nationality of foreign affiliates between French regions on the bilateral correlation of business cycles across regions. In columns 1-4, the explained variable is the bilateral correlation of GDP growth across regions. In columns 5-8, the explained variable is the bilateral correlation of HP-filtered GDPs. DisFME $E_{r r^{\prime}}$ measures the dissimilarity in the nationality of foreign affiliates for region pairs. $S_{r r^{\prime}}$ measures the dissimilarity in the economic structure of region pairs. Dist $r_{r r^{\prime}}$ is a measure of the bilateral distance between regions. Border $r_{r r^{\prime}}$ is a dummy equal to one if region pairs share a common border. Two sets of region fixed effects are introduced in all the regressions. Robust standard errors are reported. ${ }^{c},{ }^{b}$, and ${ }^{a}$ indicate significance at 10,5 , and 1 percent levels. 


\section{E Web Appendix not to be published}
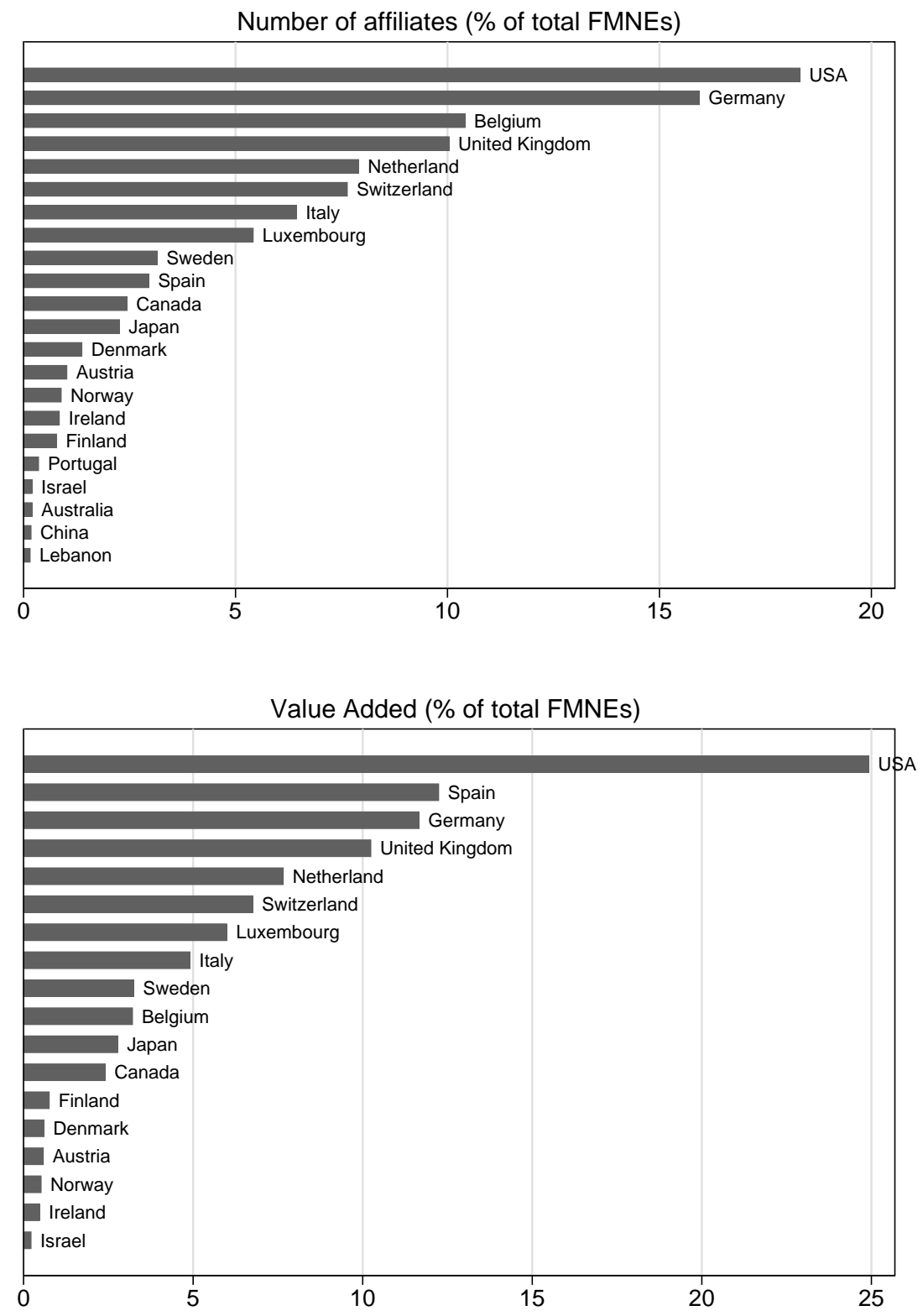

These figures present the origin of foreign affiliates in France. The graph at the top shows the repartition of multinationals by country of origin based on the number of firms. The graph at the bottom presents the repartion of firms based on value added. Only countries representing more than $1 \%$ of all affiliates are presented. The figures are based on the authors' computations relying on 2 datasets: BRN, and LIFI. 
Table 14: Foreign Affiliates and Business Cycle Correlations

\begin{tabular}{|c|c|c|c|c|c|}
\hline \multicolumn{6}{|c|}{$\begin{array}{l}\text { Dependent variable: } \rho_{c r}=\text { Correlation of growth rates of GDPs } \\
\begin{array}{ccccc}(1) & (2) & (3) & (4)\end{array}\end{array}$} \\
\hline$F M E_{c r}$ (V.A.) & $\begin{array}{l}5.327^{b} \\
(2.12)\end{array}$ & & $\begin{array}{l}4.391^{c} \\
(1.86)\end{array}$ & $\begin{array}{l}4.247^{c} \\
(1.78)\end{array}$ & $\begin{array}{c}3.731 \\
\mathbf{( 1 . 6 3 8 )}\end{array}$ \\
\hline$B T_{c r}$ & & $\begin{array}{c}20.420^{a} \\
(2.68)\end{array}$ & $\begin{array}{c}17.983^{b} \\
(2.34)\end{array}$ & $\begin{array}{c}16.102^{b} \\
(2.10)\end{array}$ & $\begin{array}{l}12.188 \\
(1.44)\end{array}$ \\
\hline$I I T_{c r}$ & & & & $\begin{array}{l}0.072^{c} \\
(1.68)\end{array}$ & $\begin{array}{l}0.070 \\
(1.64)\end{array}$ \\
\hline Border $_{c r}$ & & & & & $\begin{array}{l}0.038 \\
(0.57)\end{array}$ \\
\hline Distance $_{\text {cr }}$ & & & & & $\begin{array}{l}-0.027 \\
(-1.03)\end{array}$ \\
\hline Region FE & Yes & Yes & Yes & Yes & Yes \\
\hline Country FE & Yes & Yes & Yes & Yes & Yes \\
\hline Observations & 3402 & 3402 & 3402 & 3329 & 3329 \\
\hline$R^{2}$ & 0.690 & 0.690 & 0.691 & 0.692 & 0.692 \\
\hline
\end{tabular}

This table investigates the determinants of the bilateral comovement of business cycles between French regions and foreign GDPs. The comovement is measured by the correlation of the yearly growth of region $r$ and country $c$ GDPs over the 1990-2006 period. The explanatory variables are the value added share $\left(F M E_{c r}\right)$ made by foreign affiliates from country $c$ in region $r$, the bilateral trade $\left(B T_{c r}\right)$ between region $r$ and country $c$, normalized by the two GDPs, the share of intra-industry trade $\left(I I T_{c r}\right)$ between region $r$ and country $c$, the bilateral distance, and a dummy equal to one for contiguous region-country pairs. All regressions include region and country fixed effects. Robust t-statistics are reported between parentheses. ${ }^{c},{ }^{b}$, and ${ }^{a}$ indicate significance at 10, 5 , and 1 percent levels. 
Table 15: Foreign Affiliates and Business Cycle Correlations

\begin{tabular}{|c|c|c|c|c|c|}
\hline \multicolumn{6}{|c|}{ Dependent variable: $\rho_{c r}=$ Correlation of HP-filtered GDPs } \\
\hline & $(1)$ & $(2)$ & $(3)$ & $(4)$ & $(5)$ \\
\hline$F M E_{c r}$ (V.A.) & $\begin{array}{l}4.347^{b} \\
(2.33)\end{array}$ & & $\begin{array}{l}3.681^{b} \\
(2.05)\end{array}$ & $\begin{array}{l}3.411^{c} \\
(1.88)\end{array}$ & $\begin{array}{l}3.321^{c} \\
(1.80)\end{array}$ \\
\hline$B T_{c r}$ & & $\begin{array}{c}14.830^{c} \\
(1.86)\end{array}$ & $\begin{array}{c}12.788 \\
(1.58)\end{array}$ & $\begin{array}{c}10.172 \\
(1.27)\end{array}$ & $\begin{array}{l}8.971 \\
(1.06)\end{array}$ \\
\hline$I I T_{c r}$ & & & & $\begin{array}{c}0.090^{c} \\
(1.90)\end{array}$ & $\begin{array}{l}0.087^{c} \\
(1.84)\end{array}$ \\
\hline Border $_{c r}$ & & & & & $\begin{array}{l}-0.039 \\
(-0.55)\end{array}$ \\
\hline Distance $_{c r}$ & & & & & $\begin{array}{l}-0.032 \\
(-1.14)\end{array}$ \\
\hline Region FE & Yes & Yes & Yes & Yes & Yes \\
\hline Country FE & Yes & Yes & Yes & Yes & Yes \\
\hline Observations & 3402 & 3402 & 3402 & 3329 & 3329 \\
\hline$R^{2}$ & 0.663 & 0.663 & 0.663 & 0.665 & 0.665 \\
\hline
\end{tabular}

This table investigates the determinants of the bilateral comovement of business cycles between French regions and foreign GDPs. The comovement is measured by the correlation of the yearly growth of region $r$ and country $c$ GDPs over the 1990-2006 period. The explanatory variables are the value added share $\left(F M E_{c r}\right)$ made by foreign affiliates from country $c$ in region $r$, the bilateral trade $\left(B T_{c r}\right)$ between region $r$ and country $c$, normalized by the two GDPs, the share of intraindustry trade $\left(I I T_{c r}\right)$ between region $r$ and country $c$, the bilateral distance, and a dummy equal to one for contiguous region-country pairs. All regressions include region and country fixed effects. Robust t-statistics are reported between parentheses. ${ }^{c},{ }^{b}$, and ${ }^{a}$ indicate significance at 10,5 , and 1 percent levels. 